\title{
Quality assessment of Self Help Groups on stakeholders perspectives: A psychometrics analysis
}

\author{
Sanjay Kanti Das ${ }^{1, *}$, Amalesh Bhowal ${ }^{2}$ \\ ${ }^{1}$ Department of Commerce, Lumding College, Lumding, Nagaon, Assam-782447, India \\ ${ }^{2}$ Dept. of Commerce, Assam University, Diphu Campus, Assam-782462, India \\ Email address: \\ sanjay19711123@rediffmail.com(S. K. Das); profabhowal@gmail.com(A. Bhowal)
}

\section{To cite this article:}

Sanjay Kanti Das, Amalesh Bhowal. Quality Assessment of Self Help Groups on Stakeholders Perspectives: A Psychometrics Analysis. International Journal of Economics, Finance and Management Sciences. Vol. 1, No. 6, 2013, pp. 347-366.

doi: $10.11648 /$ j.ijefm. 20130106.22

\begin{abstract}
Micro finance has garnered significant worldwide attention as being a successful tool to meet substantial demand for financial services by low-income. India occupies a significant place and a niche in global micro finance through promotion of the Self Help Groups and the home grown SHG-Bank Linkage Programme model. It is observed that different stakeholders have promoted SHGs with different expectations and understanding, and have sorted different parameters of quality of SHGs. Thus, it is necessary to identify a common ground and set appropriate benchmarks for SHGs operation. Sixty one variables relating to quality parameters are identified and relevant perception of direct stakeholders about on whose perspective parameters to be considered for assessing Quality of SHG is incorporated in this study. The study is conducted by using multi-stage random sampling method to collect primary data from the selected Development Blocks of Nagaon districts of Assam (India). It is observed that there exists enough evidence to conclude that there are differences among direct stakeholders regarding perception of stakeholders about on whose perspective parameters to be considered for assessing quality of SHG. Further, these variables are more decisive statements or factors in this case under given methodology.
\end{abstract}

Keywords: Direct Stakeholders, North-eastern Region of India, Psychometric, Quality Parameters, Self Help Group, Assam

\section{Introduction}

To-day the Self Help Group (henceforth SHG) has grown as a worldwide movement. That is why we call the SHG as an exciting discovery in the field of poverty and unemployment reduction. Generally SHGs are expected to be platforms for women to help themselves for their social and economic empowerment $[1,2]$. This suggests that SHGs basic philosophy lies in the principle of their selfmanagement and self-regulation. The initial activities that groups generally perform include community education, information dissemination on health \& hygiene, mutual support by way of inter/intra loaning, income generation activities, services and advocacy [3]. At present the movement is considered as a weapon to fight against poverty, empowerment and development. Thus, especially in the socio-political context of India, SHGs are not just needed but most required.

During 1990's, the Government, NABARD and other funding agencies initiated several projects for the promotion of SHGs. Indira Mahila Yojana, Swashakthi, Swayamsidha, Swawalamban, Deep etc. are some of the Government projects to name in this context. Almost all these projects were implemented through Women Development Corporation, Department of Social Welfare and other Government Department, which in turn partnered with NGOs, NABARD and Rastiya Mahila Kosh (RMK) etc. and usually gave NGOs some promotional grants to form and nurture SHGs. Consequently, spread of Self Help Promoting Institutions (SHPIs) increased in a tremendous way in different parts of the country. Considering the nature of support each SHPI gives, they can be grouped into three types of agencies. They are a) Promotional agencies; b) Technical Support/Resource Agencies; and c) Funding Agencies.

Today, there are several agencies working for SHG promotion in the country. However, almost all these agencies are neither having proper collaborations with 
other agencies nor having an umbrella structure or a mentor to give a direction to their actions. APMAS (Andhra Pradesh Mahila Abhivruddhi Society), Sa-Dhan (Association of Community Development Finance Institutions), CGAP (Consultative Group to Assist the Poor) and MYRDA (Mysore Resettlement and Development Agency) etc. and so like technical and managerial support organisation has come forward for extending its strategic support and mentoring services to SHPIs in different states. Sir Dorabji Tata Trust (SDTT), ACCESS (ACCESS Microfinance Alliance), RGVN (Rashtriya Gramin Vikas Nidhi) etc., under its Assam programme, came forward to provide a long-term strategic support to NGOs/ Voluntary Organisations etc. for the strengthening of SHG movement in Assam in recent years [4].

The concept of SHGs initiated by voluntary agencies, state government (especially Department of Panchayat and Rural Development) has taken a lead in Assam. Major stakeholders in SHGs are therefore includes all SHPI inluding Promoter, Donor, Financier and the SHGs itself. In Assam, the major stakeholders in SHG formation include Department of Women and Child Development (DWCD), Department of Rural Development- SGSY, NABARD, Voluntary Organisations- NGOs, MFI- with support from Donor agencies and government programmes. It is worthwhile to mention that Department of Rural Development (under Swaranjayanti Gram Swarozgar Yojana or SGSY), Government of Assam is the largest promoter of SHG in the state of Assam [5].

Now the policy makers had also played an important role in promoting SHGs in the country. A new poverty reduction programme known as National Rural Livelihoods Mission (NRLM) is being brought in with support from the World Bank [6]. But for the sustainability, maintaining quality of groups and enrichment of SHGs and even for graduating members of the SHG, there is no direction from the government (except a few), sponsoring NGOs or Banks as to the next stage of their economic development. Here in this paper efforts are given to analyse the involvement and functioning of different stakeholders in SHGs promotion in the country in general and Assam in particular. Further, efforts are also made to examine the opinion of the direct stakeholders whether promoters or donors or financial institutions or group itself should determine the quality indicators of SHG.

\section{Key Stakeholders in SHG in North East India}

The region has a number and variety of Self Help Promoting Agencies (SHPAs). Traditionally NGOs have been in the forefront in the promotion. After the entry of District Rural Development Agency (DRDA) in 1999 in SHG promotion, it emerged as the major player. Formal financial institutions are also involved in the $\mathrm{SHG}$ promotion. A few farmers clubs are also entering in SHG promotion in recent years in the state.

One of the interesting features in the region is that communities themselves have promoted a sizeable number of SHGs. In fact, self promotion is on significant scale in the region. For example, in Kokrajhar, one SHG known as Anjali Sukhati SHG Foundation, got registered as a NGO in 2000 and promoted about 1,600 SHGs in inaccessible areas in Kokrajhar and Sidle district during the peak Bodoland agitation period. Similarly a SHG federation known as MASK, promoted by a NGO- Gana Chetana Samaj, Balipara, Sonitpur, emerged as a fully autonomous and pioneering SHG federation in North-east India and has been in forefront in sector development work not only in Assam, but also in other North-eastern states. A brief analysis on different stakeholders on SHGs functioning in North-east India in general and Assam in particular are forwarded as below.

\subsection{District Rural Development Agency (DRDA)}

DRDA is the main organ at the District level to oversee the implementation of various rural developmental programmes. It is responsible for planning and coordinating with various agencies- Governmental, Non-Governmental, technical and financial for successful programme implementation. SGSY is a centrally sponsored programme for the rural poor, launched in April, 1999 by replacing many of the earlier self-employment and allied programmes like IRDP, TRYSEM, DWCD etc. which is also run by the DRDA. SGSY aims at providing sustainable income to the rural poor and establishing a large number of micro-enterprises in the rural areas. SGSY is also attempting to promote Entrepreneur Development Programmes by setting up of 'Rural Development \& Self Employment Training Institutes (RUDSETI)' in different districts of the country.

\subsection{Centre for Microfinance \& Livelihood (CML)}

CML is a recently formed umbrella organisation for capacity building, research, collaborative interventions and policy advocacy in the social sector. CML was established in 2008, under the active support of Tata Social Welfare Trust (TSWT), an affiliate of Sir Dorabji Tata Trust, Mumbai. CML has been formed to provide a platform for resource and capacity building support to social sector in North East India.

\subsection{Rashtriya Grameen Vikas Nidhi (RGVN)}

RGVN is non-profit organisation founded in April, 1990 having its head quarter at Guwahati. RGVN operates in 14 states of the country but its focus is on North Eastern India and most of the programmes are operating in North Eastern region. RGVN also has a separate micro finance programme of its own called RGVN-Credit and Savings Programme (RGVN-CSP). Apart from other social activities, in micro finance RGVN has supported several smaller organisations through its NGO Support Programme (NGO-SP) and NGO 
Micro finance Programme (NGO-MF).

\subsection{Asomi, Guwahati}

Asomi is a leading micro finance institution (MFI), currently operating in the state of Assam. With over 53 branches and 235 employees Asomi has, just within a space of 9 years, established itself as one of Assam's leading NGO engaged in social transformation.

\subsection{Nedan Foundation, Kokrajhar}

Nedan Foundation is an NGO working in the villages of the North East India particularly in the Bodoland Territorial Council of Assam. It is trying to strengthen existing livelihoods opportunities in this region through forming groups of weavers in Kokrajhar district of Assam. The NGO is working in the North East region particularly at Bodo Territorial Council for alternative livelihoods promotion in weaving sector and helping weavers to get loans from MFIs.

\subsection{Manab Sewa Sangha, Guwahati}

An NGO working in North East India, providing micro finance services to the poor organised into groups. A development organisation involved in micro finance activities, is presently working in three districts of AssamKamrup, Nalbari and Barpeta. Following the 'group methodology', it is organising poor women into SHGs and Joint Liability Groups.

\subsection{Youth Volunteers Union, Manipur}

A Micro finance organisation imparting micro finance services to the poor based in North-East India. They are providing micro finance services to rural and urban poor in the six districts. Recently they expand their micro finance operations in urban areas of Guwahati city in Assam.

\subsection{Bandhan, Kolkata}

Bandhan is a Micro Finance Institutions working with the poor women through community participation initiatives. Presently, it is working in 29 districts of five states. After looking at the demand potential of Micro finance in North East India, it has now expanded its operations to Tripura, Assam and Meghalaya. Bandhan was set up to address the dual objective of poverty alleviation and women empowerment.

\subsection{North Eastern Region Community Resource Management Project (NERCORMP)}

The NERCORMP which was established in 1998 is a rural development project working in three states of North East India with the overall objective of improving the livelihood of vulnerable groups in a sustainable manner through improved management of resources. The project is a joint effort between North Eastern Council, Union Ministry of Development of North Eastern Region
(DoNER) and International Fund for Agricultural Development (IFAD). NERCORMP works in the North Eastern Region of India and operates in two districts each in the states of Assam, Manipur and Meghalaya. NERCORMP activities are funded by various stakeholders. The majority of the funds given to NERCORMP are by Government of India and IFAD, and rest comes from banks and contributions made by SHG/NaRMG members.

\subsection{NABARD}

NABARD is the apex Development Bank with a mandate for facilitating credit flow for promotion and development of agriculture, small-scale industries, cottage and village industries, handicrafts and other rural crafts. NABARD being an apex development financial institution with mandate for micro finance and the originator of SBLP in the country is a key stakeholder for provision of micro finance in North East India.

\subsection{Small Industrial Development Bank of India (SIDBI)}

SIDBI being an apex financial institution with significant presence in the North East India and being an agency which spurred the growth of micro finance at national level becomes a natural stakeholder for catalysing growth of micro finance in North East India. SIDBI Foundation for Micro Credit (SFMC) provides bulk loans and technical support to Micro finance Institutions in the North East region of India including Assam.

\subsection{Industrial Credit and Investment Centre of India (ICICI Bank)}

It is providing market loans and capacity building support to NGO-MFIs from North-East India and is developing a strategy to expand operations in North East. ICICI funded SIDBI Foundation for Micro Credit (SFMC) which provides bulk loans and technical support to Micro Finance Institutions in the North East region of India including Assam.

\subsection{North Eastern Development Finance Corporation (NEDFi)}

NEDFi was established on August 9, 1995 with its registered office at Guwahati, Assam. NEDFi has been jointly promoted by several financial institutions and after the creation of DoNER, NEDFi has come under the administrative control of this Ministry. NEDFi has been playing a proactive role by financing MFIs and also organising capacity building programmes for them. NEDFi aims to continue its support to micro finance, which makes it one of the stakeholders.

\subsection{Friends of Women's World Banking - India (FWWB-I)}

FWWB-I was promoted in 1982 by SEWA Bank, as an affiliate of Women's World Banking, a global network 
created to focus on the need for women's direct access to financial services. FWWB-I's mission is to provide financial and capacity building services to organisations promoting livelihoods and self-reliance of poor women. FWWB provides the services like institution building, capacity building, monitoring and assessment services for MFIs, community based organisations and partner organisations.

\subsection{Assam Financial Corporation}

Micro finance, which has added a new dimension in the economy recording exponential growth in credit delivery through SHG and Joint Liability Groups, has been recognised as an effective means of empowering the rural and economically backward section of the society. The Corporation is implementing the Chief Minister's Micro Finance Scheme (CMMF) for which the Govt. of Assam has provided a low cost loan to the needy borrowers.

\subsection{Commercial Banks and RRBs}

There are several public sector banks, cooperative societies and regional rural banks operating in North East India. State Bank of India is the biggest bank in outreach in the region. Nationalised Commercial Bank and other Private sector banks are also now expanding in North East. Apart from these banks, RRBs and Cooperative Societies are also key stakeholders in SHG promotion and financing.

\subsection{Donors and Financer}

As the micro finance industry is in its infancy in North East India, support will be imperative during this early phase. Since there is a massive need for capacity building and creating infrastructure for the MFIs, donors can play an important role in providing that initial support. Donors therefore become stakeholders in supporting MFIs on one hand and also in investing in creating an enabling environment in the region for micro finance to flourish over the long-term.

Besides these some international funding and donor institutions are also engaged in funding to the MFIs, NGOs and Livelihood projects that are operating in Assam and NER.

\subsubsection{International Fund for Agricultural Development (IFAD)}

IFAD is providing funding support to Government of India and NGOs for promotion of micro finance and livelihoods programmes in the North East (Fernandez, 2006[ 7 ]). It ran an eight-year Women's Development project (January, 1990-December, 1998). The project was implemented in six districts in India with the poor women as target group.

\subsubsection{Agricultural and Processed Food Products Export Development Authority, New Delhi}

New Delhi based organisation also act as a donor in SHG movement in North East India. They develop agricultural commodities and promote their exports in the North East region with financial assistance for market, infrastructure and quality development. It extends financial assistance through the group model.

\subsubsection{Ministry of Development of North Eastern Region (DoNER)}

DoNER has implemented the North East Rural Livelihood Project (NERLP) in four North Eastern States of Mizoram, Nagaland, Sikkim and Tripura. The aim of NERLP are to create sustainable community institutions for women SHGs, youth groups of men and women and community development groups, build capacity of community institutions for self governance, bottom up planning, democratic functioning with transparency and accountability, develop partnership of community institutions for natural resource management, micro finance, market linkages and sectoral economic services. Further, the Ministry of DONER's Plan Scheme of Capacity building and technical assistance aim to provide funding for skill development, enhancing of employability and competencies and promotion of self-employment and entrepreneurship amongst youth.

\subsubsection{Department for International Development (DFID)}

DFID is the largest bilateral donor of developmentfocused research. DFID supports poverty alleviation and capacity development and will continue to focus on inclusive growth through micro finance, livelihood improvements, and urban reforms over the period 20122016 in selected states, including Bihar, Madhya Pradesh, and West Bengal. DFID also supports the urban basic services component of the Jawaharlal Nehru National Urban Renewal Mission (JNNURM), which is executed by the Ministry of Housing and Poverty Alleviation. ADB collaborates with DFID in support of capacity development in Kolkata and Madhya Pradesh, with similar collaboration proposed in Assam.

\subsubsection{State Government}

The major government programme promoting SHGs and channeling large funds for poverty reduction is the SGSY programme. Other state and central government programmes too have promoted SHGs in large numbers viz. Ministry of Development of North Eastern Region's North East Rural Livelihood Project, Chief Minister's Micro finance Scheme, North Eastern Region Community Resource Management Project, Chief Minister's Assam Bikash Yojona etc.

Thus, SHPIs- whether NGOs, banks or State Governments, have been playing a vital role in promoting, nurturing and sustaining the SHG programmes under SBLP. SHPIs and MFIs are the channels to provide the financial services. SHPIs groom SHGs which ultimately deliver financial services. The quality of SHGs being nurtured depends on the SHPIs and their own capacity. SHGs are an important financial services delivery channel and hence SHPIs gain a lot of importance. These SHPIs are several 
NGOs operating in all the states of North East India and are key stakeholders in one of the streams of micro finance. Some of the major MFIs operating in North East India include: Arohan Financial Services, RGVN-CSP, ASOMI, IIRM, Bandhan, Prochesta, YVU, VVD, NEREFS and UNNACO etc. The CML data base is published in February 2010 focusing the sector overview of NGOs, NGO-MFIs and MFIs of Assam reported that there are 84 NGO-MFIs, 7 MFIs and 121 NGOs operating in Assam. A few NGOs that are engaged in SHG promotion in Assam includes Asomi-MFI, Bosco Reach Out, North Eastern Region Community Resource Management Project, RGVN, NEICORD, NERCORMP, ASOMI, IIRM, RGVN- CSP, Prochesta, Grameen Sahara etc.

The structure of major stakeholders that are engaged in micro financing and SHG movement in Assam are outlined as below Fig. 1 .

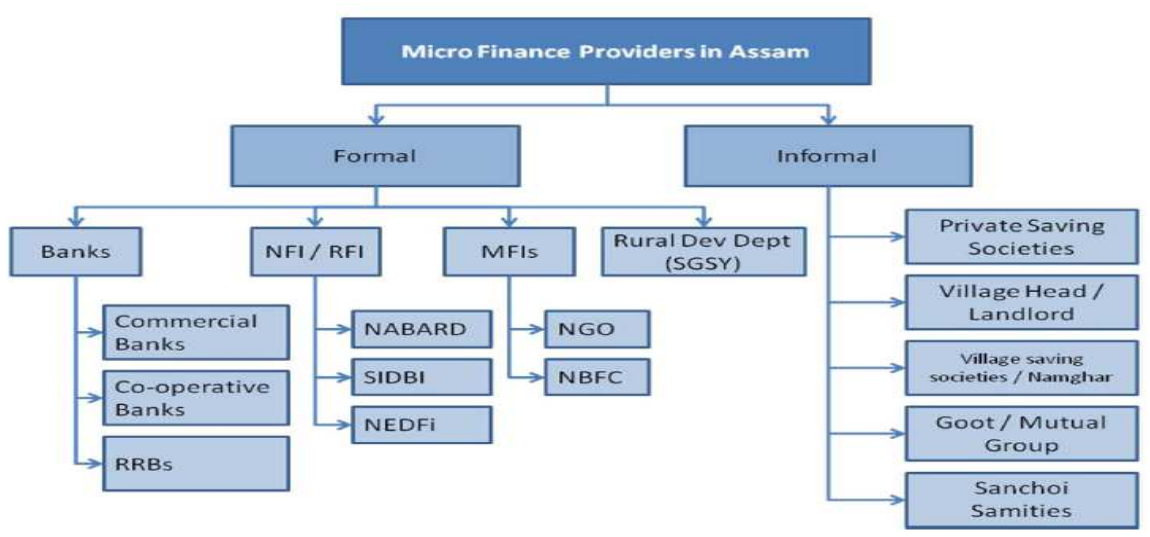

Figure 1. Micro finance providers in Assam. (Source: Author)

\section{Quality Assessment Parameters of Self Help Groups}

While studying the quality of SHGs, BASICS [ 8 ] pointed out poor quality of SHGs and argue how to ensure the quality of SHGs in an environment of exponential growth. The study observed that due to the focused growth of the SBLP, the quality of SHGs has come under stress [9, $10,11,12])$. This is reflected particularly in indicators such as the poor maintenance of books and accounts, irregular meeting, high transaction cost, low recovery rate etc. At the same time, recent evaluation study and research findings also observed the poor quality of SHGs in the country [13, $14,15,16,17,18,19,20]$. The findings of other microstudies on SHGs performance also reflects the miserable state of quality of SHGs in different parts of India [21, 22, $23,24,25,26,27,28]$. Such revelations are quite alarming as quality of SHGs has a direct bearing on the future prospects of the SHG movement.

Thus, it is observed that quality is the major challenge that the SHG movement is confronted with at this point of time in the country. A large number of bankers, DRDA officials and NGOs are using the Critical Rating Index (CRI) developed by NABARD's leadership to promote bank linkage and for offering other government avenues. The CRI basically consists of two sets of variables, viz. Governance and systems related variables and financial variables. SHG Performance Measurement Tool [29] helps the SHPIs to measure the quality of SHGs and to identify the areas of strengths and weaknesses of SHGs that would in turn help them to design their capacity building initiatives for SHGs in a more focused and cost effective manner. This tool also helps banks to understand and assess SHGs performance in the required detail for credit linkage. To measure the performance of SHGs, seven broad indicators such as group constitution, organisational discipline, organisational systems, financial management and performance, external linkages, activities undertaken by group/members and self-reliance in managing affairs had been taking into account. Sa-Dhan [30] made a comparative study of assessment tools developed by various organisation viz. National Bank for Rural Development (NABARD), BASIX, Mysore Resettlement and Development Agency (MYRADA), CARE, Andhra Pradesh Mahila Abhivruddhi Society (APAMAS) etc. and have identified eight broad thematic areas with various indicators and their respective benchmarks. The study identifies eight broad major indicators viz. Group constitution, orgnisational discipline, organisational systems, financial management, credit policy, external linkage etc., to access the quality of SHGs. Reddy observed that the state of SHGs identifies key areas of weakness which undermine the sustainability of SHG movement. He identifies the major areas such as financial management, governance and human resource ranges from weak to average quality for a majority of SHGs [31]. Sen \& Sircar conducted a study on SHGs in West Bengal keeping the regularity of meetings, participation of members, group management, regularity of savings, loan disbursement, loan recovery, accounts and records, links with PRI, livelihood engagement and social action as the indicators of quality assessment of SHG [32]. APMAS addressed a wide range of issues including cases of dropouts from SHGs and 
internal politics, and issues of social harmony and social justice, community actions, book-keepings, equity, defaults and recoveries and sustainability of SHGs [33]. In another study [34] sixteen variables are indentified to access the SHGs quality viz. Feeling of homogeneity/solidarity, velocity of internal lending, governance issues, attendance in meeting, member awareness about financial, transactions involvement in village issues etc. Haryana Community Forestry Project [35] assessed the quality of SHGs in a self style way which comprises nine broad indicators which includes organisational capacity, saving and credit, financial management, micro-enterprises, skill development, awareness \& attitudes, empowerment \& influence, networks \& linkages and plans \& visions. Roy undertaken quality assessment of SHGs in West Bengal using twenty indicators like group meeting, members' participation, group discipline, savings, micro-credit, financial management, economic and social initiatives and linkages with institutions [36]. Sharma argue that quality aspects of SHGs, literacy goals, and social focus of community mobilisation efforts need to be stressed while assessing the quality of SHGs [37]. Further, social indicators need to be mandatorily included in SHG (programme) quality assessment parameters. Parashar believed that quality of SHGs should be stressed upon more than their numbers (i.e., quantity) and urged quality parameters would include not just financial and physical performance of the group, but also parameters to assess economic and livelihood goal achievement, social status improvement and entitlement access facilitation [38]. Bhanawat pointed out that quality of SHGs and the SHG programme should always be prioritised over quantity [39]. Nirantar Charter for SHG (2008[i]) recommended that all promoting agencies are responsible for the outcome and performance of SHGs. Further, the Charter recommended that indicators for rating SHG's quality and performance should include social aspects, besides institutional and financial ones. Shetty in this study constructed a sustainability index comprising of eight indicators viz. leadership, regularity of meetings, decision making, record keeping, accounting and monitoring, network and membership, conflict resolving capacity and dropout rate etc [40]. Sahu assessed the quality of SHG in Northwest India based on the thirteen indicators covering group formation, homogeneity in economic status, social status, group processes etc. on which the researcher given weightage [41]. Vipinkumar et al., 2013[42] advocated the group dynamics of SHGs which was measured by the index called Group Dynamics Effectiveness Index (GDEI) developed by Vipinkumar and Singh, 1998[43] with appropriate modifications. The GDEI was operationally defined as the sum-total of the forces

[i] This Charter was developed and finalised by over 200 civil society groups/development practitioners/researchers/ policymakers in various meetings and workshops held in Hyderabad (2007), Lucknow (2007), New Delhi (2007), Bhopal (2008) and Nagercoil (2008). This process was facilitated by Nirantar - A Centre for Gender and Education, Delhi (www.nirantar.net) among the members of SHG based on the sub-dimensions, such as participation, influence and styles of influence, decision making procedures, task functions, maintenance functions, group atmosphere, membership, feelings, norms, empathy, interpersonal trust and achievements of SHG.

Working towards a common acceptance and wide use of quality as well as organisational capacity assessment processes for SMFIs, APMAS has developed a Quality Assessment System [44] 'GRADES' in collaboration with M-CRIL. Roy studied quality of the services of some sample MFIs of Assam is assessed in terms of thirteen variables under two performance dimensions viz., range of services and attributes of the services offered to the their clients [45 ]. ENABLE, 2012[ii] identified the key variables in the SHG grading tool and pointed to the fact that book keeping is a serious weakness in more than half of the sample SHGs. Another area of concern in the SHG movement is democracy within the groups. Though many SHGs do talk about leadership rotation and regular elections in SHGs, less than half of the sample SHGs practiced that and the situation is not very different in other SHGs.

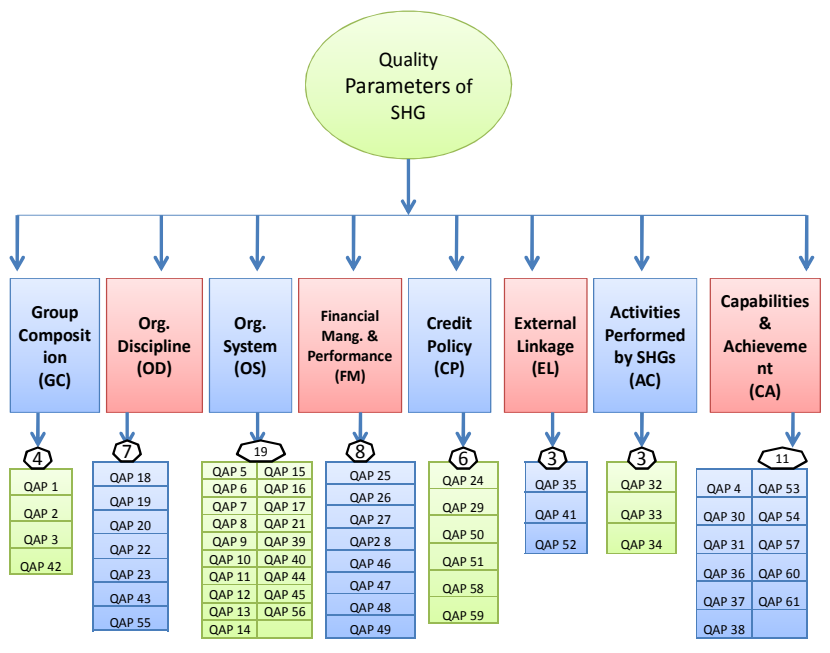

Figure 2. Quality parameters of SHGs. (Source: Designed based on survey of literature)

Several rating systems for micro finance interventions and SHGs have been developed in the past. Further, all these rating tools speak different languages in assessing the quality of SHGs. Feeling of homogeneity/ solidarity, velocity of internal lending, governance issues, attendance in meeting, member awareness about financial, transactions involvement in village issues, organisational capacity, savings and credit, financial management, micro enterprise

[ii] To address the above challenges and to contribute to a healthy, balanced and sustainable growth of the SHG sector in the country, a National Network Enabling Self Help Movement in India (ENABLE) was formed in 2007 with a vision of vibrant self help movement in India. To strengthen its evidence based advocacy through research, ENABLE conducted a comprehensive research study on the 'quality and sustainability of SHGs' in eight states, viz. Andhra Pradesh, Assam, Bihar, Gujarat, Karnataka, Maharashtra, Rajasthan and West Bengal. 
development, awareness and attitudes, networks and linkages, and empowerment and influence etc. are common areas which needs to be considered while assessing quality of SHGs. Therefore, from the survey of literature, sixty one variables relating to quality parameters are identified (Fig. 2) and relevant perception of direct stakeholders whether promoters or donors or financial institutions or group itself should determine the quality indicators of SHG is perceived in this study.

\section{Statement of the Problem}

Different organisations have promoted or supported SHGs from a different perspective and agenda. The outlook of SHGs largely depends on how the promoters see them in the long run, whether they are intended to be temporary or permanent organisations. Looking across the prevalent perspectives on SHGs, it could be said that they are loaded with wide range of expectations on the part of different stakeholders. It is observed that different stakeholders have promoted SHGs with different expectations and understanding, and have sorted different parameters to assess quality of SHGs. Thus, it is necessary to identify a common ground and set appropriate benchmarks for SHGs operation. Moreover, in defining the domain of standards for the quality assessment, several issues and questions present themselves. These derive from the fact of the nonformal nature of SHGs, the limited literacy and management experience of SHG members, the large number and types of SHG promoters with their particular agendas and methodology often operating in conflict with each other. One modest effort in this context has been initiated by Sa-Dhan [46] in preparing and publishing a discussion paper on "Quality Parameters of SHGs". This paper has provided clues to the unresolved issues of quality parameters.

\section{Objective of the Study}

The study is pursued keeping in view the following main objectives

a) To examine the opinion of the direct stakeholders whether promoters or donors or financial institutions or group itself should determine the quality indicators of SHG.

b) To forward conclusion based on the findings of the study.

\section{Research Hypotheses}

Given the survey of literature and objectives, the study is pursued to test the following statistical hypothesis:

Ho: There is no significant association in the opinion of the direct stakeholders of SHGs regarding perception of stakeholders about on whose perspective parameters to be considered for assessing Quality of SHG.

\section{Methodology}

Psychometrics refers to the measurement of abilities, traits, and attitudes with questionnaires and tests. It is the field of study concerned with the theory and technique of psychological measurement, which includes the measurement of knowledge, abilities, attitudes, personality traits, and educational measurement. Here effort is given to understand the perceptions of direct stakeholders of SHGs about on whose perspective parameters to be considered for assessing Quality of SHG (61 selected quality parameters). There are two important psychometric properties- reliability and validity which are considered in this study. Reliability deals with the extent to which a measure is repeatable or stable. Validity refers to the extent to which a study actually captures or measures what it purports to examine.

The study uses both primary data and secondary data. Multi-stage random sampling method is used for the present study to collect primary data. Nagaon district of Assam being the native district of the scholar was purposively chosen for the present study. The study was conducted in 2012. At the next level, five Development Blocks are selected randomly. In the later stage, three revenue villages from each of the selected Development blocks are purposively selected. From each revenue village, three SHG members, who are associated actively, are selected randomly. Further, 12 Financial institutions i.e. nationalised commercial bank and RRBs (operating in the study area); 10 Donors and 34 promoters including banks, NGOs, NGO-MFIs, Farmers Clubs and Government Departments are also selected randomly who are directly associated with the sampled SHGs. Thus, the total sample size is 100 (Considered adequate by researchers [47, 48, 49, $50,51]$ ). Primary data was collected using pre-tested questionnaire. Secondary data was collected from report on Micro finance Status by NABARD, Branch Banking Status of RBI, NEDFi Databank on Northeast, SBI Local Head Office, Zonal and Regional Offices of Commercial Banks, Head Offices of Regional Rural Banks, Census India, NSSO, Directorate of SGSY (Guwahati- Assam), DRDA (Nagaon- Assam), Government of Assam, Reports of State Level Bankers Committee, Assam and Economic Survey, and literature published by different institutions on Micro finance have been used. The important variables were formulated and the relevant data collected from the field were coded and analysed using SPSS (Statistical Package for Social Sciences) software. Perceptions of direct stakeholders whether promoters or donors or financial institutions or group itself should determine the quality indicators of SHG were expressed based on binary Scale where $\mathrm{No}=0$ and $\mathrm{Yes}=1$. Further, the data collected using the questionnaire method was analysed using the measures of descriptive statistics like mean, median and standard deviation. Cronbach alpha, one sample KolmogorovSmirnov Test, Shapiro-Wilk Test, Kruskal Wallis test, and Cross Tabulation analysis was applied in analysing and interpreting the data. 


\section{Profile of the Respondents}

This section explains profile of sample respondent's who are direct stakeholders of SHGs viz. Promoters, Donors, Financial Institutions and the Group members.

\subsection{Socio-economic Profile of Group Members}

\subsubsection{Gender of Group Members}

The study consists of respondents from all groups i.e. both male and female as shown in Table 1. Out of 44 respondents belonging to Group members, 24 (54.5\%) are male and $20(45.5 \%)$ are female. Sincere effort is given to cover reasonable number of members from each class so that study is free from gender bias. Further, it is observed from the field report and other secondary resources that in the study area there are ample number of women SHGs.

Table 1. Distribution of the Sample Respondents by Gender

\begin{tabular}{llcc}
\hline & & Group Members \\
\hline \multirow{2}{*}{ Gender of SHG } & Male & Count & 24 \\
Member & & \% of Total & $54.5 \%$ \\
& Female & Count & 20 \\
& & \% of Total & $45.5 \%$ \\
Total & Count & 44 \\
& & \% of Total & $100.0 \%$ \\
\hline
\end{tabular}

Source: Compiled from the Questionnaire

\subsubsection{Age of Group Members}

Table 2. Distribution of the Sample Respondents by Age

\begin{tabular}{lccc}
\hline & & & Group Members \\
\hline & Below 30 yr & Count & 11 \\
Age of SHG & & \% of Total & $25.0 \%$ \\
Member in & \multirow{2}{*}{$30-40 \mathrm{yr}$} & Count & 12 \\
Years & & \% of Total & $27.3 \%$ \\
& \multirow{2}{*}{40 \& above } & Count & 21 \\
& & \% of Total & $47.7 \%$ \\
Total & & Count & 44 \\
& & \% of Total & $100.0 \%$ \\
\hline
\end{tabular}

Source: Compiled from the Questionnaire

The study consists of respondents from all age groups. Distribution of the sample respondents by age composition is furnished in Table 2. It is pertinent from the table that majority of the sample respondents belong to $40 \&$ above age group $(47.7 \%)$. At the next level, majority of the respondents are $30-40$ years of age $(27.3 \%)$, while study also consists of $25 \%$ of the respondents, who are below 30 years of age. Thus, it is revealed from the study that matured aged respondents are actively participating in SHGs.

\subsubsection{Caste of Group Members}

Caste is the social variable. Table 3 present distributions of the sample respondents by caste. It is observed from the table that the study covers all caste groups namely General Castes, Scheduled Castes (SCs) and Scheduled Tribes (STs). It is depicted from the table that $50 \%$ of the sample respondents are from general category, followed by $29.5 \%$ of the respondents from SC category, $15.9 \%$ of the respondents from ST category and the rest $4.5 \%$ of the respondents are from other category.

Table 3. Distribution of the Sample Respondents by Caste

\begin{tabular}{lllc}
\hline & & & Group Members \\
\hline & General & Count & 22 \\
& & \% of Total & $50.0 \%$ \\
Caste \& Sub & Schedule & Count & 13 \\
Caste of SHG & Caste & \% of Total & $29.5 \%$ \\
Member & Schedule & Count & 7 \\
& Tribes & \% of Total & $15.9 \%$ \\
& Others & Count & 2 \\
& & \% of Total & $4.5 \%$ \\
Total & & Count & 44 \\
& & \% of Total & $100.0 \%$ \\
\hline
\end{tabular}

Source: Compiled from the Questionnaire

\subsubsection{Social Status of Group Members}

The study constitutes respondents from different members from all community having different social status, namely, Most Backward Community, Backward Community and Forward Community. Distribution of the sample respondents by social status is provided in Table 4 . It is delineated from the table that largest percentage of the sample respondents belong to Backward Community $(61.4 \%)$, while $31.8 \%$ of the respondents belong to Forward Community and $6.8 \%$ of the respondents belong to Most Backward Community.

Table 4. Distribution of the Sample Respondents by Social Status

\begin{tabular}{|c|c|c|c|}
\hline & & & Group Members \\
\hline \multirow{6}{*}{$\begin{array}{l}\text { Social Status } \\
\text { of SHG } \\
\text { Member }\end{array}$} & \multirow{2}{*}{$\begin{array}{l}\text { Most Backward } \\
\text { Community }\end{array}$} & Count & 3 \\
\hline & & $\%$ of Total & $6.8 \%$ \\
\hline & \multirow{2}{*}{$\begin{array}{l}\text { Backward } \\
\text { Community }\end{array}$} & Count & 27 \\
\hline & & $\%$ of Total & $61.4 \%$ \\
\hline & \multirow{2}{*}{$\begin{array}{l}\text { Forward } \\
\text { Community }\end{array}$} & Count & 14 \\
\hline & & $\%$ of Total & $31.8 \%$ \\
\hline \multirow{2}{*}{ Total } & & Count & 44 \\
\hline & & $\%$ of Total & $100.0 \%$ \\
\hline
\end{tabular}

Source: Compiled from the Questionnaire

\subsubsection{Economic Status of Group Members}

Table 5 presents distribution of the sample respondents by Economic Status of family. It is portrayed from the table that huge proportion of the sample respondents are Others i.e. wage earner, disguised labour, non-agricultural labourers, private employees, job seeker (44\%), 34.1\% belongs to Below Poverty Level, 15.9\% belongs to Green Card Holder and only $9.1 \%$ of the sample respondents are the Job Card Holder. 
Table 5. Distribution of the Sample Respondents by Economic Status

\begin{tabular}{lllc}
\hline & & & Group Members \\
\hline & Below Poverty & Count & 15 \\
& Level & \% of Total & $34.1 \%$ \\
Economic & Green Card & Count & 7 \\
Status of & & \% of Total & $15.9 \%$ \\
SHG Member & Job Card Holder & Count & 4 \\
& & \% of Total & $9.1 \%$ \\
& Others & Count & 18 \\
& & \% of Total & $40.9 \%$ \\
Total & & Count & 44 \\
& & $\%$ of Total & $100.0 \%$ \\
\hline
\end{tabular}

Source: Compiled from the Questionnaire

\subsubsection{Duration of Membership in SHG of Group Members}

Table 6 below depicts the number of years a sample respondent being a member of the SHG. It is observed that $38.6 \%$ of the sample respondents remains member of a SHG during $1-4$ years, $34.1 \%$ of the respondents are members of SHG during 4-5 years, $18.2 \%$ of the respondents are members of SHG more than 6 years while only $9.1 \%$ of the respondents are members of SHG during 5-6 years.

Table 6. Distribution of the sample respondents by Duration of Membership

\begin{tabular}{lclc}
\hline & & & Group Members \\
\hline & \multirow{2}{*}{$1-4 \mathrm{yr}$} & Count & 17 \\
& & \% of Total & $38.6 \%$ \\
& & Count & 15 \\
Duration of & $4-5 \mathrm{yr}$ & \% of Total & $34.1 \%$ \\
Membership in & & Count & 4 \\
SHG & $5-6$ yr & \% of Total & $9.1 \%$ \\
& & Count & 8 \\
& Above 6 yr & \% of Total & $18.2 \%$ \\
Total & & Count & 44 \\
& & \% of Total & $100.0 \%$ \\
\hline
\end{tabular}

Source: Compiled from the Questionnaire

\subsubsection{Literacy Level of Group Members}

Table 7 shows distribution of the sample respondents by educational level. It is interesting to note from the table that only $45.5 \%$ of the sample respondents are above 10th Standard and the rest of the respondents are either neo literates or literates. The study comprises $25 \%$ of the respondents, who are neo-literates i.e. 10th Standard. It is found from the table that $9.1 \%$ of the respondents among literates have completed above primary education but less than $10^{\text {th }}$ standard. Of the sample surveyed, $20.5 \%$ of them have studied up to primary education level.
Table 7. Distribution of the Sample Respondents by Education Level

\begin{tabular}{lllc}
\hline & & & Group Members \\
\hline & Primary & Count & \% of Total \\
& & Count & $20.5 \%$ \\
Educational & Std. & \% of Total & 4 \\
Level of SHG & & Count & $9.1 \%$ \\
Member & 10th Std. & \% of Total & 11 \\
& & Count & $25.0 \%$ \\
& Above 10th & \% of Total & 20 \\
Total & & Count & $45.5 \%$ \\
& & \% of Total & 44 \\
\hline
\end{tabular}

Source: Compiled from the Questionnaire

\subsubsection{Annual Income of Group Members}

Distribution of the sample respondents by annual income is presented in Table 8 . It is inferred from the table that annual income of the majority of the sample respondents ranges up to Rs. 50, 000 (56.8\%). At the next level, $43.2 \%$ of the sample respondents' annual income of the sample respondents ranges from Rs. 50,000 - Rs. 1 lakhs.

Table 8. Distribution of the Sample Respondents by Annual Income

\begin{tabular}{lllc}
\hline & & Group Members \\
\hline \multicolumn{2}{c}{$\begin{array}{l}\text { Upto Rs. 50 } \\
\text { Thousand }\end{array}$} & Count & 25 \\
Annual Income of & \% of Total & $56.8 \%$ \\
SHG Member & Rs. 50- Rs. 1 & Count & 19 \\
& lakhs & \% of Total & $43.2 \%$ \\
Total & Count & 44 \\
& & \% of Total & $100.0 \%$ \\
\hline
\end{tabular}

Source: Compiled from the Questionnaire

\subsection{Profile of Other Direct Stakeholder}

"Stakeholders" means the persons or institutions with whom any stake or interest is vested or created to facilitate the promotion of SHG movement, which shall include the regulators, promoters, donor, financier, educators and facilitators of the SHG movement. Major stakeholders in SHGs are, therefore includes all SHPI i.e. Promoter, Donor, Financier and the SHGs itself.

Since from survey of literature and field study it is observed that there is no specific boundary regarding the nature and functioning of Self Help Promoting Institutions (SHPIs). It is observed that an SHPI can act both as promoter \& donor. Similarly Government departments are also acting both promoter and Donor vis-a-vis financier. Therefore the investigator collected information from such stakeholders who performed two or three tasks such as promoter, donor and financier, through separate sets of questionnaire.

SHPIs, whether Farmers club, NGOs, banks or State governments, have been playing a vital role in promoting, 
nurturing and sustaining the SHG programmes under SBLP in Assam. The major promoter of SHGs in the study districts are District Rural Development Agency (for SGSY scheme), Banks and NGOs. A few NGO-MFI are also promoting SHGs in the study district. In this study respondent as promoter includes some officials of NGOs such as ASOMI, Prochesta-MFI, RGVN-MFI Commercial banks, Rasthiya Krishi Vighyan Yojana, SIRD, DDMNABARD, ASFABC, Agriculture Departments, Farmers Club etc. who are engaged in SHG promotion are included. In this way out of 100 respondents, 34 respondents belong to Promoter category.

"Donors and investors" encompasses a range of funding agencies, including bilateral donors, foundations, multilateral development banks, and socially oriented private investors. While NABARD and RMK etc. remains a major donor to NGOs and SHG institutions in India and have been receiving a fraction of required funds for their development. In the study districts NABARD, State Government under SGSY and NGO-MFIs are the major donors in SHG funding. In this study respondents belonging form Donor includes some officials of NGOMFI such as ASOMI, Prochesta-MFI, RGVN-MFI, Dristi Foundation, RuTAG-NE, Srimanta Sankardeb Sangstha; Officials of District Veterinary \& Animal Husbandry, NABARD, NERCRMP, SIRD, Agriculture Departments etc. In this way out of 100 respondents, 10 respondents comprises Donor category.

SHPIs include banks, NGOs, NGO-MFIs and state governments. Here in the state and even in the study district SHPIs acts both promoter and financier. However for the sake of study, we have collected perceived opinions of different stakeholders on different scale of capacity, i.e. bank is considered financier, promoter and donor. In this study respondents belonging form Financial Institutions includes Officials of State bank of India and other nationalised commercial banks, RRBs i.e. AGVB etc. In this way out of 100 respondents, 10 represented from Financial Institutions. Section below depicts the detailed profile of Promoter, Donor, and Financial Institutions that are included in the present study.

Table 9. Distribution of the Sample Respondents by Nationality of Stakeholders

\begin{tabular}{|c|c|c|c|c|c|}
\hline & & \multicolumn{3}{|c|}{ Stakeholders Category } & \multirow{2}{*}{ Total } \\
\hline & & Promoter & Donor & FIs & \\
\hline \multirow{2}{*}{ Originality } & \multirow{2}{*}{$\begin{array}{l}\text { 三 Count } \\
\text { 三્三 } \% \text { of Total }\end{array}$} & 34 & 10 & 12 & 56 \\
\hline & & $100.0 \%$ & $100.0 \%$ & $100.0 \%$ & $100.0 \%$ \\
\hline \multirow{2}{*}{ Total } & Count & 34 & 10 & 12 & 56 \\
\hline & $\%$ of Total & $100.0 \%$ & $100.0 \%$ & $100.0 \%$ & $100.0 \%$ \\
\hline
\end{tabular}

Source: Compiled from the Questionnaire

\subsubsection{Originality/Nationality of Stakeholders}

It is observed from the Table 9 below that all the respondents belong to different categories are originated from India.

\subsubsection{Nature of Promoting Organisation}

Distribution of the sample respondents by Nature of Promoting Organisation is presented in Table 10. It is observed that majority of respondents comes from other Government agencies (55.9\%) and Government departments $(20.6 \%)$. The share of other promoting organisation includes NGO-Universal (2.9\%), NGONation-hood (8.8\%) and NGO-Region hood (5.9\%). Therefore, it may also be concluded that a large variety of institutions that are engaged in the promotion of SHGs in the study districts are basically promoted by other government agencies i.e. DRDA (SGSY) is the major promoter of SHG in the study district.

Table 10. Distribution of the Sample Respondents by Nature of Promoting Organisation

\begin{tabular}{|c|c|c|c|}
\hline & & & Promoter \\
\hline \multirow{12}{*}{ 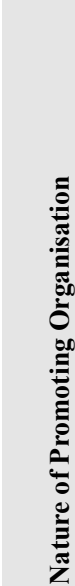 } & \multirow{2}{*}{ Govt. Depts } & Count & 7 \\
\hline & & $\%$ of Total & $20.6 \%$ \\
\hline & \multirow{2}{*}{ Other Govt. Agencies } & Count & 19 \\
\hline & & $\%$ of Total & $55.9 \%$ \\
\hline & \multirow{2}{*}{ NGO- Universal } & Count & 1 \\
\hline & & $\%$ of Total & $2.9 \%$ \\
\hline & \multirow{2}{*}{ NGO- Nation hood } & Count & 3 \\
\hline & & $\%$ of Total & $8.8 \%$ \\
\hline & \multirow{2}{*}{ NGO-Region hood } & Count & 2 \\
\hline & & $\%$ of Total & $5.9 \%$ \\
\hline & \multirow{2}{*}{ NGO- Statehood } & Count & 2 \\
\hline & & $\%$ of Total & $5.9 \%$ \\
\hline \multirow{2}{*}{ Total } & & Count & 34 \\
\hline & & $\%$ of Total & $100.0 \%$ \\
\hline
\end{tabular}

Source: Compiled from the Questionnaire

\subsubsection{Place of Location of Stakeholders}

Distribution of the sample respondents by Place of Location of Stakeholders is presented in Table 11. It is observed that majority of respondents belonging to Promoter located in Assam (52.9\%), 41.2\% of the respondents belonging to Promoter originated from outside North East Region (NER) while 5.9\% of the respondents belonging to Promoter originated from Outside Assam but within NER. Similarly, majority of respondents belonging to Donor located in Assam (60\%) and equal number of respondents belonging to Donor originated from outside NER and from Outside Assam but within NER (20\% each). Further, it is observed that majority of respondents belonging to Financial Institutions have functioning at all India level $(66.7 \%)$ while $33.3 \%$ of the respondents belonging to Financial Institutions are originated within Assam. However, majority of stakeholder have originated from Assam (50\%), 7.14\% respondents from other states of NER of India and $42.86 \%$ respondents whose existence is situated at all India level. 
Table 11. Distribution of the Sample Respondents by Place of Location where from Stakeholders Functioning

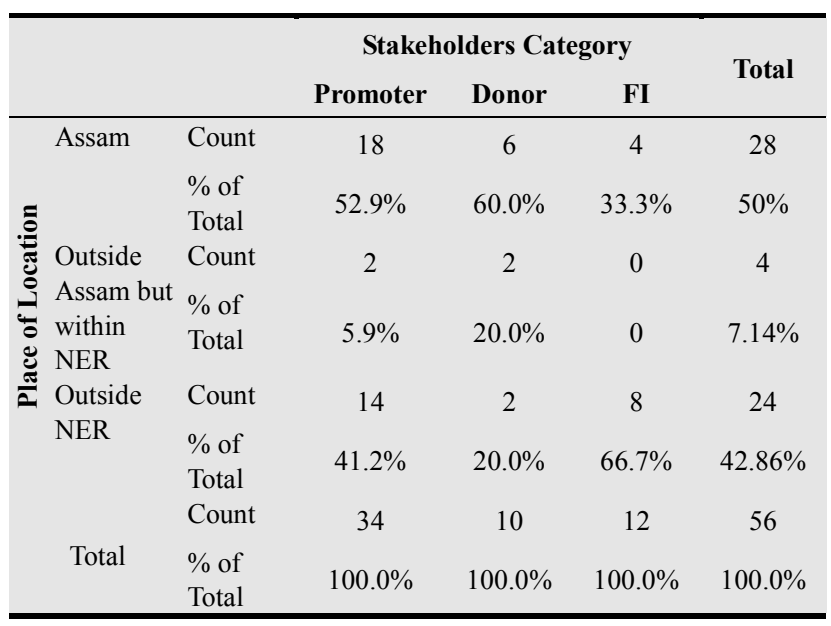

Source: Compiled from the Questionnaire

\subsubsection{Nature of Programme/ Project of Stakeholders}

Distribution of the sample respondents by Nature of Programme is presented in Table 12. It is observed that majority of respondents promoting or linked with SGSY $(53.33 \%)$, while $60.71 \%$ of respondents linked other programmes. Further, it is observed that majority of the respondents belonging to Promoter and Donor connected with others programme i.e. not connected with SGSY while cent percent financial institutions are connected with Government sponsored SGSY scheme.

Table 12. Distribution of the Sample Respondents by Nature of Programme of Stakeholders

\begin{tabular}{|c|c|c|c|c|c|}
\hline & & \multicolumn{3}{|c|}{ Stakeholders Category } & \multirow{2}{*}{ Total } \\
\hline & & Promoter & Donor & FI & \\
\hline \multirow{4}{*}{ 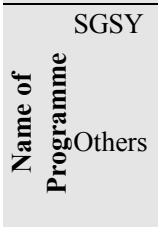 } & Count & 19 & 3 & 12 & 34 \\
\hline & $\%$ of Total & $55.9 \%$ & $30.0 \%$ & $100.0 \%$ & $60.71 \%$ \\
\hline & Count & 15 & 7 & 0 & 22 \\
\hline & $\%$ of Total & $44.1 \%$ & $70.0 \%$ & 0 & $39.29 \%$ \\
\hline \multirow[t]{2}{*}{ Total } & Count & 34 & 10 & 12 & 56 \\
\hline & $\%$ of Total & $100.0 \%$ & $100.0 \%$ & $100.0 \%$ & $100.0 \%$ \\
\hline
\end{tabular}

Source: Compiled from the Questionnaire

\subsubsection{Nature of Promotion by Stakeholders}

Distribution of the sample respondents by Nature of Promotion is presented in Table 13. It is observed that majority of respondents promoting or linked with financial assistance $(53.57 \%)$, while $46.43 \%$ of respondents linked both financial \& non-financial i.e. financial and training. Further, it is observed that majority of the respondents belonging to Donor category are connected with financial and non-financial assistance (90\%) while 91.7\% of respondents belonging to Financial Institutions are provided only financial assistance.
Table 13. Distribution of the Sample Respondents by Nature of Promotion by Stakeholder's Category

\begin{tabular}{|c|c|c|c|c|c|c|}
\hline & & & \multicolumn{3}{|c|}{ Stakeholders Category } & \multirow{2}{*}{ Total } \\
\hline & & & Promoter & Donor & FI & \\
\hline \multirow{4}{*}{ 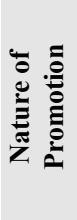 } & & Count & 18 & 1 & 11 & 30 \\
\hline & Financial & $1 \%$ of Total & $52.9 \%$ & $10.0 \%$ & $91.7 \%$ & $53.57 \%$ \\
\hline & Both & Count & 16 & 9 & 1 & 26 \\
\hline & & $\%$ of Total & $47.1 \%$ & $90.0 \%$ & $8.3 \%$ & $46.43 \%$ \\
\hline \multirow{2}{*}{ Total } & & Count & 34 & 10 & 12 & 56 \\
\hline & & $\%$ of Total & $1000 \%$ & $1000 \%$ & $100.0 \%$ & $1000 \%$ \\
\hline
\end{tabular}

Source: Compiled from the Questionnaire

\subsubsection{Recovery Percentage of SHG Promoted by Stakeholders}

Distribution of the sample respondents by Recover Percentage of SHG Promoted is presented in Table 14. It is observed the table that majority of respondents from all categories of stakeholders $(63.64 \%)$ whose recovery percentage is ranged within $50 \%-75 \%$. Further, it is observed that $16.7 \%$ respondents belonging to financial institutions who reported recovery percentage is above $75 \%$.

Table 14. Distribution of the Sample Respondents by Recovery Percentage of $\mathrm{SHG}$

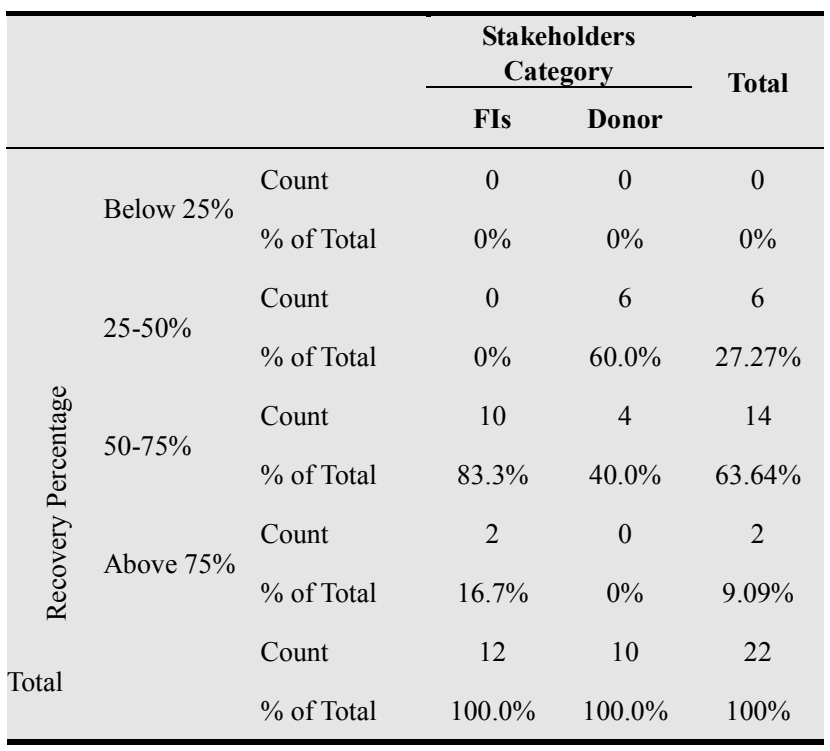

Source: Compiled from the Questionnaire

\subsubsection{Impact Assessment by Stakeholders}

Distribution of the sample respondents by performing of Performance Assessment is presented in Table 15. It is observed from the table that $21.43 \%$ of respondents from all categories of stakeholders conducted impact assessment. Only $50 \%$ of Donor and $20.6 \%$ of respondents belonging to Promoter reported that they conducted such impact assessment. 
Table 15. Distribution of the Sample Respondents by Impact Assessment

\begin{tabular}{|c|c|c|c|c|c|c|}
\hline & & & \multicolumn{3}{|c|}{ Stakeholders Category } & \multirow{2}{*}{ Total } \\
\hline & & & Promoter & FIs & Donor & \\
\hline \multirow{4}{*}{ 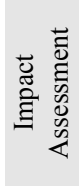 } & \multirow{2}{*}{ No } & Count & 27 & 12 & 5 & 39 \\
\hline & & $\%$ of Total & $79.4 \%$ & $100.0 \%$ & $50.0 \%$ & $69.64 \%$ \\
\hline & \multirow{2}{*}{ Yes } & Count & 7 & 0 & 5 & 12 \\
\hline & & $\%$ of Total & $20.6 \%$ & $0 \%$ & $50.0 \%$ & $21.43 \%$ \\
\hline \multirow{2}{*}{ Total } & & Count & 34 & 12 & 10 & 56 \\
\hline & & $\%$ of Total & $100.0 \%$ & $100.0 \%$ & $100.0 \%$ & $100.0 \%$ \\
\hline
\end{tabular}

Source: Compiled from the Questionnaire

\subsubsection{Quality Assessment Conducted by Stakeholders}

Distribution of the sample respondents by performing of Quality Assessment is presented in Table 16. It is observed from the table that $32.14 \%$ respondents from all categories of stakeholders conducted quality assessment. Only $32.4 \%$ of promoter respondents and 25 of Financial Institutions respondents and $40 \%$ of Donor respondents reported that they perform such quality assessment.

Table 16. Distribution of the Sample Respondents by Quality Assessment

\begin{tabular}{|c|c|c|c|c|c|c|}
\hline & & & \multicolumn{3}{|c|}{ Stakeholders Category } & \multirow{2}{*}{ Total } \\
\hline & & & Promoter & FIs & Donor & \\
\hline \multirow{4}{*}{ 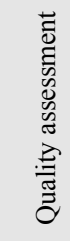 } & \multirow[t]{2}{*}{ No } & Count & 23 & 9 & 6 & 38 \\
\hline & & $\%$ of Total & $\begin{array}{c}67.6 \\
\%\end{array}$ & $\begin{array}{c}75.0 \\
\%\end{array}$ & $\begin{array}{c}60.0 \\
\%\end{array}$ & $67.86 \%$ \\
\hline & \multirow[t]{2}{*}{ Yes } & Count & 11 & 3 & 4 & 18 \\
\hline & & $\%$ of Total & $\begin{array}{c}32.4 \\
\%\end{array}$ & $\begin{array}{c}25.0 \\
\%\end{array}$ & $\begin{array}{c}40.0 \\
\%\end{array}$ & $32.14 \%$ \\
\hline \multirow[t]{2}{*}{ Total } & & Count & 34 & 12 & 10 & 56 \\
\hline & & $\%$ of Total & $\begin{array}{c}100 . \\
0 \%\end{array}$ & $\begin{array}{c}100 . \\
0 \%\end{array}$ & $\begin{array}{c}100 . \\
0 \%\end{array}$ & $100.0 \%$ \\
\hline
\end{tabular}

Source: Compiled from the Questionnaire

Table 17. Distribution of the Sample Respondents by Performance Assessment

\begin{tabular}{|c|c|c|c|c|c|c|}
\hline & & & \multicolumn{3}{|c|}{ Stakeholders Category } & \multirow{2}{*}{ Total } \\
\hline & & & Promoter & FIs & Donor & \\
\hline \multirow{4}{*}{ 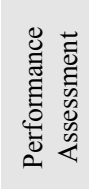 } & No & Count & 15 & 5 & 4 & 24 \\
\hline & & $\%$ of Total & $44.1 \%$ & $41.7 \%$ & $40.0 \%$ & $42.85 \%$ \\
\hline & Yes & Count & 19 & 7 & 6 & 32 \\
\hline & & $\%$ of Total & $55.9 \%$ & $58.3 \%$ & $60.0 \%$ & $57.14 \%$ \\
\hline \multirow[t]{2}{*}{ Total } & & Count & 34 & 12 & 10 & 56 \\
\hline & & $\%$ of Total & $100.0 \%$ & $100.0 \%$ & $100.0 \%$ & $100.0 \%$ \\
\hline
\end{tabular}

Source: Compiled from the Questionnaire

\subsubsection{Performance Assessment Conducted by Stakeholder}

Distribution of the sample respondents by performing of Performance Assessment is presented in Table 17. It is observed from the table that $57.14 \%$ of respondents from all categories of stakeholders conducted Performance assessment.

\subsubsection{Nature of Donor Organisation}

Distribution of the sample respondents by Nature of Donor Organisation is presented in Table 18. It is observed that majority of respondents comes from Government Departments (50\%), while $20 \%$ respondents belong to NGO and $30 \%$ belong to Trust.

Table 18. Distribution of the Sample Respondents by Nature of Donor Organisation

\begin{tabular}{|c|c|c|c|}
\hline & & & Donor \\
\hline \multirow{6}{*}{ 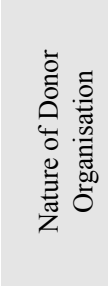 } & \multirow{2}{*}{ Govt. Dept } & Count & 5 \\
\hline & & $\%$ of Total & $50.0 \%$ \\
\hline & \multirow{2}{*}{ Trust } & Count & 3 \\
\hline & & $\%$ of Total & $30.0 \%$ \\
\hline & \multirow{2}{*}{ NGO } & Count & 2 \\
\hline & & $\%$ of Total & $20.0 \%$ \\
\hline \multirow{2}{*}{ Total } & & Count & 10 \\
\hline & & $\%$ of Total & $100.0 \%$ \\
\hline
\end{tabular}

Source: Compiled from the Questionnaire

\subsubsection{Nature of Financial Institution}

Distribution of the sample respondents by Nature of Financial Institution is presented in Table 19. It is observed that majority of respondents comes from Public Sector Financial Institutions like SBI and Other nationalised commercial banks available in the study district (75\%), while $25 \%$ respondents belong to Regional Rural bank i.e. AGVB.

Table 19. Distribution of the Sample Respondents by Nature of Financial Institutions

\begin{tabular}{|c|c|c|}
\hline & & Financial Institutions \\
\hline \multirow{5}{*}{ Nature of FIs } & Count & 9 \\
\hline & Public Sector FI & \\
\hline & $\%$ of Total & $75.0 \%$ \\
\hline & Count & 3 \\
\hline & $\%$ of Total & $25.0 \%$ \\
\hline \multirow{2}{*}{ Total } & Count & 12 \\
\hline & $\%$ of Total & $100.0 \%$ \\
\hline
\end{tabular}

Source: Compiled from the Questionnaire

\section{Analysis \& Discussion}

\subsection{Reliability Test}

The result of the reliability test of the opinion of different stakeholders on 61elements of quality parameters of SHG reveals that Cronbach's Alpha is 0.715 which is acceptable $[52,53,54])$.

\subsection{Validity}

The instrument used in this study was developed by the researchers after an extensive review of literature in the 
subject and related theory and following survey design procedures found in the literature $[55,56,57,58]$. We drafted a pool of 81 items, which were submitted to 4 content judges for review and to determine the face and content validity of the items. These judges had expertise in research design, survey design, micro finance management and group development. This panel of content judges included local university faculty members and micro finance practitioners of repute. We requested this panel to check the instrument items for clarity, length, time to complete, difficulty in understanding and answering questions, flow of questions, appropriateness of questions based on the research topic, any recommendations for revising the survey questions (e.g., add, substituted or delete), and overall utility of the instrument. Based on their feedback, some items of the sub-scales were revised according to appropriate demographic circumstances of the study district. At this stage, the 81 items were reduced to 61 .

\subsection{Descriptive Statistics}

Further, the descriptive scale statistics on the perception of different stakeholders on selected quality parameter of SHG denotes the mean value 28.06, variance 57.895 and Standard Deviation is 7.609 (Table 22).

\subsection{Test of Normality}

In our case, since we have only 61 elements, the ShapiroWilk Test is used to test normality of the data (Total score). From the Table 20, the p-value is 0.003 , hence we conclude that the data do not come from population which a normal distribution (Table 20). Hence, non-parametric Tests are suitable.

Table 20. Tests of Normality on Perception of Stakeholders about on whose Perspective Parameters to be considered for Assessing Quality of SHG

\begin{tabular}{lccccccc}
\hline & \multicolumn{3}{c}{ Kolmogorov-Smirnov $^{\mathbf{a}}$} & \multicolumn{3}{c}{ Shapiro-Wilk } \\
\cline { 2 - 7 } & Statistic & df & Sig. & Statistic & df & Sig. \\
\hline Overall & & & & & & \\
Score on SQAP & .107 & 100 & .007 & .958 & 100 & .003 \\
\hline
\end{tabular}

Lilliefors Significance Correction. Source: Compiled from the Questionnaire

\subsection{Development of Scale for Measuring Intensity of Desire}

To assess the perception of direct stakeholders of SHGs about on whose perspective parameters to be considered for assessing Quality of SHG, the scale contains 61 items. The maximum one respondent can score in each of the items is 1. Therefore, maximum possible score is 61 . Similarly, the minimum one respondent can score in each of the items is 0 . Therefore, minimum possible score is also 0 . The interval of score from 0 to 61 was divided into two equal classes to represent two different levels of perception [59, 60 ]. Further, the respective scale is also represented on percentage scale for better understanding about perception of stakeholders of SHGs whether they should determine the Quality Indicators of SHG (Table 25). The scale is given in the Table 21 .

Table 21. Scale Interpretation on Perception of Stakeholders about on whose Perspective Parameters to be considered for Assessing Quality of SHG

\begin{tabular}{ccc}
\hline $\begin{array}{c}\text { Scale based on } \\
\text { Score }\end{array}$ & $\begin{array}{c}\text { Scale based on } \\
\text { percentage }\end{array}$ & Interpretation \\
\hline $0-30.4$ & Below $50 \%$ & $\begin{array}{c}\text { Low level of } \\
\text { intensity } \\
\text { High level of } \\
\text { intensity }\end{array}$ \\
\hline
\end{tabular}

Source: Author

The mean value of the data is found to be 28.06 which is within the range of ' $0-30.4$ ' which means that the direct stakeholders have 'low level of intensity' about on whose perspective parameters to be considered for assessing Quality of SHG. Further, from the Table 22, it is also observed that Donor and Group member have also 'low level of intensity' about on whose perspective parameters to be considered for assessing Quality of SHG, while Promoter and Financial Institutions have 'high level of intensity'. Thus, the score of intensity of desire of direct stakeholders of SHGs about on whose perspective parameters to be considered for assessing Quality of SHG is low.

Table 22. Descriptive Scale Statistics on the Perception of Different Stakeholders about on whose Perspective Parameters to be considered for Assessing Quality of $\mathrm{SHG}$

\begin{tabular}{cccc}
\hline Stakeholders Category & Mean & N & Std. Deviation \\
\hline Promoter & 31.29 & 34 & 6.544 \\
Donor & 29.10 & 10 & 5.507 \\
Financial Institutions & 30.83 & 12 & 6.162 \\
Group Members & 24.57 & 44 & 7.825 \\
Total & 28.06 & 100 & 7.609 \\
\hline
\end{tabular}

\subsection{Kruskal Wallis Test}

Total of intensity of desire of the each direct stakeholder (respondents) was arrived at by totaling individual scores perceived by different respondents on 61 elements of quality parameters and its justification revealed by means of Cronbach's Alpha. The total score (i.e. total of SQAP) so arrived also do not follow normal distribution which is tested by Shapiro-Wilk Test and Kolmogorov-Smirnov Test. Further, total of intensity of desire of direct stakeholders of SHGs about on whose perspective parameters to be considered for assessing Quality of SHG, is thus an interval scale which is higher than the ordinal scale. In other words interval data are more precise than nominal and ordinal data because the interval scale contains meaningful distances [61]. Since the data do not follow the normal distribution, therefore non parametric ANOVA which is to be applied to test whether there exists any differences of 
opinion between groups (i.e. promoters, donors, Financial institutions and group members) in respect of the scale to measure intensity of desire of the different direct stakeholders and hence, KW Test was applied. In fact, Kruskal-Wallis test evaluates differences in medians among groups. With the Kruskal-Wallis test, a chi-square statistic is used to evaluate differences in mean ranks to assess the null hypothesis that the medians are equal across the groups [62]. The Rank order on the perceptions of Stakeholders

Table 23. Rank order on the perceptions of Stakeholders about on whose Perspective Parameters to be considered for Assessing Quality of SHG

\begin{tabular}{lccc}
\hline & Stakeholders Category & N & Mean Rank \\
\hline & Promoter & 34 & 62.10 \\
TOTAL OF & Donor & 10 & 53.15 \\
SQAP & Financial Institutions & 12 & 63.79 \\
& Group Members & 44 & 37.31 \\
& Total & 100 & \\
\hline
\end{tabular}

In other words, it is the non-parametric version of ANOVA and a generalised form of the Mann-Whitney test method since it permits two or more groups. From the Test Statistics, at the $\alpha=0.05$ level of significance, there exists enough evidence to conclude that there is differences among direct stakeholders regarding perception of Stakeholders about on whose perspective parameters to be considered for assessing Quality of SHG (Table 24).

Table 24. Kruskal-Wallis Test on Perception of Stakeholders about on whose Perspective Parameters to be considered for Assessing Quality of SHG

\begin{tabular}{ccc}
\hline Test Statistics $^{\mathbf{a}, \mathbf{b}}$ & Overall Score of SQAP & Decision \\
\hline Chi-Square & 17.221 & Since p-value $=0.001 \leq$ \\
df & 3 & 0.05, we reject the null \\
hypothesis.
\end{tabular}

a. Kruskal Wallis Test

b. Grouping Variable: Stakeholders Category

Source: Compiled from the Questionnaire

\subsection{Cross Tabulation Analysis}

Moreover, to assess the perception of Stakeholders of SHGs regarding the perspectives of Promoters, Donors, Financial Institutions and Group itself while determining the quality indicators of SHGs, cross tabulation analysis is conducted. It depicts percentage of perception of different stakeholders of SHGs regarding the perspectives of Promoters, Donors, Financial Institutions and Group itself while determining the quality indicators of SHGs (Table 25).

Thus, if percentage of agreement in the opinion is $50 \%$ or above, it is assumed that there exists a 'high level of intensity of desire' or high level of desire to assess the quality of SHGs on the considered parameters by the considered stakeholders. Again, if percentage of agreement in the opinion is below $50 \%$, it is assumed that there exists a 'low level of intensity of desire' or low level of desire to assess the quality of SHGs on the considered parameters by the considered stakeholders. Thus, it is observed from the Table 25 that-

a. All the stakeholders of SHGs i.e. promoters or donors or financial institutions or group itself has perceived strong level of desire to assess the quality of SHGs on thirty nine parameters like 'Vision based functioning of SHG (SQAP 1)'; 'Degree of participation of members in decision making (SQAP 4)'; Elected group leaders and office bearers (SQAP 10); Practice of rotating leadership (SQAP 11)'; 'Prescribed level of maintenance of records (SQAP 14)'; 'Recording of the loans sanctioned to the SHG (SQAP 15)'; 'Accessibility of books and accounts by the members (SQAP 17)'; Attendance of members of SHG's in group meeting (SQAP 18)'; 'Degree of unanimity among the members while arriving at decision in SHG (SQAP 19)'; 'Division amongst members because of disagreements in meeting of SHG (SQAP 20)'; 'Transparency in operation of SHG (SQAP 21)'; 'Regularity in savings of SHG (SQAP 22)'; Fixation of rate of interest (SQAP 24)'; 'Ability of SHG to manage different rate of interest on loans (SQAP 25)'; 'Decision of SHG on loan sanctioning (SQAP 26)'; 'Productive purposes group loans (SQAP 29)'; 'Acquiring of vocational skills by members of SHG (SQAP 30)'; 'Establishment of new micro-enterprises by the SHG/members (SQAP 31)'; 'Degree of linkage with Banks \& other agencies by the SHG (SQAP 35)'; 'Degree of self reliance in managing social affairs by the SHG members (SQAP 36)'; 'Degree of self reliance in managing economic affairs by the SHG members (SQAP 37)'; 'Degree of self reliance in managing group affairs by the SHG members (SQAP 38)'; 'Practice of proper monitoring system by the SHG (SQAP 39)'; 'Practice of quality enhancement mechanism in the SHG (SQAP 40)'; 'Existence of multiple agencies in group promotion (SQAP 41)'; 'Duration of existence of the SHG (SQAP 42)'; Frequency and regularity of group meetings (SQAP 43)'; Practice of responsibility sharing by members (SQAP 44)'; Proper and adequate management of group funds(SQAP 46)'; 'Degree of leverage of external funds of the SHG (SQAP 47)'; 'Level of financial sustainability of the SHG (SQAP 48)'; Degree of exposure of investment portfolio risk assumed by SHG (SQAP 49)'; Presence of rigid internal lending criteria(SQAP 50)'; Strict adherence to purpose and coverage of loan by the SHG (SQAP 51)'; 'Practice about the study of track records with lenders at the time of loan sanctioning by the SHG (SQAP 52)'; Degree of dropout rate of members of the SHG (SQAP 55); 'Practice of up to date recording of 'minutes' of meetings by the SHG (SQAP 56)'; Mechanism for maintaining groups distinct identity in 
the community (SQAP 57); Practice of the doctrine 'all members needing loans have got them at least once' (SQAP 58); Practice of the principle of 'office bearers have taken loan only after the need of all others has been met' (SQAP 59); and 'Accessibility \& up to date information about total group saving, interest earned and default amount, if any by the SHG members (SQAP 60)'.

b. All the stakeholders of SHGs i.e. promoters or donors or financial institutions or group itself has perceived low desire to assess the quality of SHGs on four parameters like 'Caste based formation of SHG (SQAP 3)'; 'Pre-fixed rules and regulation for running the group (SQAP 5)'; 'Codification of rules \& regulations of the SHGs (SQAP 6)'; 'Organisation of community events by the SHG (SQAP 34)'.

c. It is interesting to note that only the Group members have perceived strong level of desire on the elements like Practice of updating rules (SQAP 7); Level of awareness of members of SHG (SQAP 8), Following of the basic accounting norms (SQAP 12); Following of scientific book keeping (SQAP 13); Recording of other fund requirements (SQAP 16); Loan recovery policy of SHG (SQAP 28); Involvement in social and community supportive activities by SHG (SQAP 32); Level of awareness of SHG members about issues of social harmony and social justice (SQAP 33); Level of literacy of SHGs members (SQAP 53); and Awareness level of SHG members on banking / government programmes (SQAP 54) while other direct stakeholders have low level of desire on the said elements.

d. Again, statement relating to quality parameters like 'Gender based formation of SHG (SQAP 2)' where all stakeholders except Financial Institutions has perceived high level of desire to assess the quality of SHGs on their own perspective. Further, statement relating to quality parameters like 'Strict following of the group norms by all the members (SQAP 9)' where Financial Institutions and Promoters have perceived high level of desire but Donor \& Group members has perceived low level of desire to assess the quality of SHGs at their own perspective. On the statement relating to quality parameters like 'Elected group leaders and office bearers (SQAP 10)'; Policy of keeping emergency funds by SHG (SQAP 27); 'Revision of mandatory savings (SQAP 23) and 'Level of awareness about the functions of cluster associations (Federations/JLG) of SHGs members (SQAP 61) where all the stakeholders except Financial Institutions have perceived high level of desire to assess the quality of SHGs at their own perspective. Again, on the statement relating to quality parameters 'observing of proper auditing system' (SQAP 45) wherein all the stakeholders except Donor have perceived high level of desire to assess the quality of SHGs at their own perspective.

Table 25. Perception of Stakeholders of SHGs (expressed in percentage) whether they should determine the Quality Indicators of SHG

\begin{tabular}{|c|c|c|c|c|c|c|}
\hline Code & Statement relating to quality parameters & Promoter & Donor & FIs & $\begin{array}{c}\text { Group } \\
\text { Members }\end{array}$ & Total \\
\hline SQAP-1 & Vision based functioning of SHG & $94.1 \%$ & $100.0 \%$ & $91.7 \%$ & $97.7 \%$ & $96.0 \%$ \\
\hline SQAP-2 & Gender based formation of SHG & $64.7 \%$ & $70.0 \%$ & $41.7 \%$ & $72.7 \%$ & $66.0 \%$ \\
\hline SQAP- 3 & Caste based formation of SHG & $35.3 \%$ & $30.0 \%$ & $41.7 \%$ & $47.7 \%$ & $41.0 \%$ \\
\hline SQAP-4 & $\begin{array}{l}\text { Degree of participation [ measured in Percentage] of } \\
\text { members in decision making }\end{array}$ & $88.2 \%$ & $100.0 \%$ & $100.0 \%$ & $100.0 \%$ & $96.0 \%$ \\
\hline SQAP-5 & Pre-fixed rules and regulation for running the group & $29.4 \%$ & $30.0 \%$ & $16.7 \%$ & $45.5 \%$ & $35.0 \%$ \\
\hline SQAP- 6 & Codification of rules \& regulations of the SHGs & $20.6 \%$ & $30.0 \%$ & $16.7 \%$ & $45.5 \%$ & $32.0 \%$ \\
\hline SQAP-7 & Practice of updating rules & $23.5 \%$ & $20.0 \%$ & $16.7 \%$ & $50.0 \%$ & $34.0 \%$ \\
\hline SQAP- 8 & Level of awareness of members of SHG & $38.2 \%$ & $10.0 \%$ & $33.3 \%$ & $54.5 \%$ & $42.0 \%$ \\
\hline SQAP-9 & Strict following of the group norms by all the members & $61.8 \%$ & $30.0 \%$ & $83.3 \%$ & $47.7 \%$ & $55.0 \%$ \\
\hline SQAP-10 & Elected group leaders and office bearers & $61.8 \%$ & $100.0 \%$ & $50.0 \%$ & $75.0 \%$ & $70.0 \%$ \\
\hline SQAP-11 & Practice of rotating leadership & $82.4 \%$ & $100.0 \%$ & $91.7 \%$ & $68.2 \%$ & $79.0 \%$ \\
\hline SQAP-12 & Following of the basic accounting norms & $23.5 \%$ & $30.0 \%$ & $16.7 \%$ & $54.5 \%$ & $37.0 \%$ \\
\hline SQAP-13 & Following of scientific book keeping & $14.7 \%$ & $20.0 \%$ & $8.3 \%$ & $59.1 \%$ & $34.0 \%$ \\
\hline SQAP-14 & Prescribed level of maintenance of records & $94.1 \%$ & $80.0 \%$ & $100.0 \%$ & $84.1 \%$ & $89.0 \%$ \\
\hline SQAP-15 & Recording of the loans sanctioned to the SHG & $100.0 \%$ & $100.0 \%$ & $100.0 \%$ & $93.2 \%$ & $97.0 \%$ \\
\hline SQAP-16 & Recording of other fund requirements & $20.6 \%$ & $20.0 \%$ & $8.3 \%$ & $88.6 \%$ & $49.0 \%$ \\
\hline SQAP-17 & Accessibility of books and accounts by the members & $100.0 \%$ & $100.0 \%$ & $100.0 \%$ & $100.0 \%$ & $100.0 \%$ \\
\hline SQAP-18 & Attendance of members of SHG's in group meeting & $100.0 \%$ & $100.0 \%$ & $100.0 \%$ & $77.3 \%$ & $90.0 \%$ \\
\hline SQAP-19 & $\begin{array}{l}\text { Degree of unanimity among the members while arriving at } \\
\text { decision in SHG }\end{array}$ & $85.3 \%$ & $100.0 \%$ & $91.7 \%$ & $90.9 \%$ & $90.0 \%$ \\
\hline SQAP-20 & $\begin{array}{l}\text { Division amongst members because of disagreements in } \\
\text { meeting of SHG }\end{array}$ & $88.2 \%$ & $90.0 \%$ & $91.7 \%$ & $84.1 \%$ & $87.0 \%$ \\
\hline SQAP-21 & Transparency in operation of SHG & $97.1 \%$ & $100.0 \%$ & $100.0 \%$ & $95.5 \%$ & $97.0 \%$ \\
\hline SQAP-22 & Regularity in savings of SHG & $97.1 \%$ & $100.0 \%$ & $91.7 \%$ & $100.0 \%$ & $98.0 \%$ \\
\hline
\end{tabular}




\begin{tabular}{|c|c|c|c|c|c|c|}
\hline Code & Statement relating to quality parameters & Promoter & Donor & FIs & $\begin{array}{c}\text { Group } \\
\text { Members }\end{array}$ & Total \\
\hline SQAP-23 & Revision of mandatory savings of SHG & $52.9 \%$ & $70.0 \%$ & $25.0 \%$ & $84.1 \%$ & $65.0 \%$ \\
\hline SQAP-24 & Fixation of rate of interest & $85.3 \%$ & $80.0 \%$ & $75.0 \%$ & $90.9 \%$ & $86.0 \%$ \\
\hline SQAP-25 & Ability of SHG to manage different rate of interest on loans & $97.1 \%$ & $80.0 \%$ & $100.0 \%$ & $88.6 \%$ & $92.0 \%$ \\
\hline SQAP-26 & Decision of SHG on loan sanctioning & $100.0 \%$ & $100.0 \%$ & $100.0 \%$ & $95.5 \%$ & $98.0 \%$ \\
\hline SQAP-27 & Policy of keeping emergency funds by SHG & $55.9 \%$ & $70.0 \%$ & $33.3 \%$ & $77.3 \%$ & $64.0 \%$ \\
\hline SQAP-28 & Loan recovery policy of SHG & $20.6 \%$ & $10.0 \%$ & $8.3 \%$ & $70.5 \%$ & $40.0 \%$ \\
\hline SQAP-29 & Productive purposes group loans & $94.1 \%$ & $100.0 \%$ & $83.3 \%$ & $100.0 \%$ & $96.0 \%$ \\
\hline SQAP-30 & Acquiring of vocational skills by members of SHG & $100.0 \%$ & $100.0 \%$ & $100.0 \%$ & $97.7 \%$ & $99.0 \%$ \\
\hline SQAP-31 & $\begin{array}{l}\text { Establishment of new micro-enterprises by the } \\
\text { SHG/members }\end{array}$ & $94.1 \%$ & $100.0 \%$ & $100.0 \%$ & $90.9 \%$ & $94.0 \%$ \\
\hline SQAP-32 & $\begin{array}{l}\text { Involvement in social and community supportive activities } \\
\text { by SHG }\end{array}$ & $23.5 \%$ & $30.0 \%$ & $25.0 \%$ & $59.1 \%$ & $40.0 \%$ \\
\hline SQAP-33 & $\begin{array}{l}\text { Level of awareness of SHG members about issues of social } \\
\text { harmony and social justice }\end{array}$ & $17.6 \%$ & $0.0 \%$ & $25.0 \%$ & $54.5 \%$ & $33.0 \%$ \\
\hline SQAP-34 & Organisation of community events by the SHG & $26.5 \%$ & $40.0 \%$ & $25.0 \%$ & $36.4 \%$ & $32.0 \%$ \\
\hline SQAP-35 & Degree of linkage with Banks \& other agencies by the SHG & $100.0 \%$ & $100.0 \%$ & $100.0 \%$ & $100.0 \%$ & $100.0 \%$ \\
\hline SQAP-36 & $\begin{array}{l}\text { Degree of self reliance in managing social affairs by the } \\
\text { SHG members }\end{array}$ & $94.1 \%$ & $100.0 \%$ & $100.0 \%$ & $95.5 \%$ & $96.0 \%$ \\
\hline SQAP-37 & $\begin{array}{l}\text { Degree of self reliance in managing economic affairs by the } \\
\text { SHG members }\end{array}$ & $94.1 \%$ & $100.0 \%$ & $100.0 \%$ & $95.5 \%$ & $96.0 \%$ \\
\hline SQAP-38 & $\begin{array}{l}\text { Degree of self reliance in managing group affairs by the } \\
\text { SHG members }\end{array}$ & $100.0 \%$ & $100.0 \%$ & $100.0 \%$ & $95.5 \%$ & $98.0 \%$ \\
\hline SQAP-39 & Practice of proper monitoring system by the SHG & $100.0 \%$ & $100.0 \%$ & $100.0 \%$ & $100.0 \%$ & $100.0 \%$ \\
\hline SQAP-40 & Practice of quality enhancement mechanism in the SHG & $100.0 \%$ & $100.0 \%$ & $100.0 \%$ & $100.0 \%$ & $100.0 \%$ \\
\hline SQAP-41 & Existence of multiple agencies in group promotion & $91.2 \%$ & $100.0 \%$ & $100.0 \%$ & $95.5 \%$ & $95.0 \%$ \\
\hline SQAP-42 & Duration of existence of the SHG & $85.3 \%$ & $90.0 \%$ & $91.7 \%$ & $81.8 \%$ & $85.0 \%$ \\
\hline SQAP-43 & Frequency and regularity of group meetings & $88.2 \%$ & $90.0 \%$ & $91.7 \%$ & $65.9 \%$ & $79.0 \%$ \\
\hline SQAP-44 & Practice of responsibility sharing by members & $97.1 \%$ & $90.0 \%$ & $100.0 \%$ & $56.8 \%$ & $79.0 \%$ \\
\hline SQAP-45 & Observing of proper auditing system & $79.4 \%$ & $40.0 \%$ & $83.3 \%$ & $72.7 \%$ & $73.0 \%$ \\
\hline SQAP-46 & Proper and adequate management of group funds & $91.2 \%$ & $60.0 \%$ & $100.0 \%$ & $81.8 \%$ & $85.0 \%$ \\
\hline SQAP-47 & Degree of leverage of external funds of the SHG & $97.1 \%$ & $80.0 \%$ & $100.0 \%$ & $88.6 \%$ & $92.0 \%$ \\
\hline SQAP-48 & Level of financial sustainability of the SHG & $97.1 \%$ & $90.0 \%$ & $100.0 \%$ & $93.2 \%$ & $95.0 \%$ \\
\hline SQAP-49 & $\begin{array}{l}\text { Degree of exposure of investment portfolio risk assumed by } \\
\text { SHG }\end{array}$ & $70.6 \%$ & $80.0 \%$ & $50.0 \%$ & $90.9 \%$ & $78.0 \%$ \\
\hline SQAP-50 & Presence of rigid internal lending criteria & $94.1 \%$ & $60.0 \%$ & $100.0 \%$ & $95.5 \%$ & $92.0 \%$ \\
\hline SQAP-51 & $\begin{array}{l}\text { Strict adherence to purpose and coverage of loan by the } \\
\text { SHG }\end{array}$ & $88.2 \%$ & $70.0 \%$ & $91.7 \%$ & $88.6 \%$ & $87.0 \%$ \\
\hline SQAP-52 & $\begin{array}{l}\text { Practice about the study of track records with lenders at the } \\
\text { time of loan sanctioning by the SHG }\end{array}$ & $97.1 \%$ & $90.0 \%$ & $100.0 \%$ & $90.9 \%$ & $94.0 \%$ \\
\hline SQAP-53 & Level of literacy of SHGs members & $5.9 \%$ & $10.0 \%$ & $8.3 \%$ & $52.3 \%$ & $27.0 \%$ \\
\hline SQAP-54 & $\begin{array}{l}\text { Awareness level of SHG members on banking / government } \\
\text { programmes }\end{array}$ & $14.7 \%$ & $20.0 \%$ & $16.7 \%$ & $56.8 \%$ & $34.0 \%$ \\
\hline SQAP-55 & Degree of dropout rate of members of the SHG & $64.7 \%$ & $70.0 \%$ & $50.0 \%$ & $95.5 \%$ & $77.0 \%$ \\
\hline SQAP-56 & $\begin{array}{l}\text { Practice of up to date recording of 'minutes' of meetings by } \\
\text { the SHG }\end{array}$ & $91.2 \%$ & $80.0 \%$ & $100.0 \%$ & $100.0 \%$ & $95.0 \%$ \\
\hline SQAP-57 & $\begin{array}{l}\text { Mechanism for maintaining groups distinct identity in the } \\
\text { community }\end{array}$ & $82.4 \%$ & $50.0 \%$ & $83.3 \%$ & $88.6 \%$ & $82.0 \%$ \\
\hline SQAP-58 & $\begin{array}{l}\text { Practice of the doctrine 'all members needing loans have got } \\
\text { them at least once' }\end{array}$ & $88.2 \%$ & $60.0 \%$ & $91.7 \%$ & $88.6 \%$ & $86.0 \%$ \\
\hline SQAP-59 & $\begin{array}{l}\text { Practice of the principle of 'office bearers have taken loan } \\
\text { only after the need of all others has been met' }\end{array}$ & $85.3 \%$ & $60.0 \%$ & $91.7 \%$ & $88.6 \%$ & $85.0 \%$ \\
\hline SQAP-60 & $\begin{array}{l}\text { Accessibility \& up to date information about total group } \\
\text { saving, interest earned and default amount, if any by the } \\
\text { SHG members }\end{array}$ & $97.1 \%$ & $90.0 \%$ & $100.0 \%$ & $93.2 \%$ & $95.0 \%$ \\
\hline SQAP-61 & $\begin{array}{l}\text { Level of awareness about the functions of cluster } \\
\text { associations (Federations/JLG) of SHGs members }\end{array}$ & $52.9 \%$ & $90.0 \%$ & $41.7 \%$ & $90.9 \%$ & $72.0 \%$ \\
\hline
\end{tabular}

Source: Compiled from the Questionnaire 


\section{Conclusion}

The North-eastern Region of India has a number and variety of Self Help Promoting Agencies (SHPAs). Traditionally NGOs have been in the forefront in the promotion. After the entry of DRDA in 1999 in SHG promotion, it emerged as the major player. Formal and informal financial institutions are also involved in the SHG promotion. A few farmers clubs, Government departments and all India and international bodies are also engaged in SHGs promotion either directly or indirectly in recent years.

SHPIs, whether NGOs, banks or State governments, have been playing a vital role in promoting, nurturing and sustaining the SHG programmes under SBLP. SHPIs and MFIs are the channels to provide the financial services. SHPIs groom SHGs which ultimately deliver financial services. The quality of SHGs being nurtured depends on the SHPIs and their own capacity. SHGs are an important financial services delivery channel and hence SHPIs gain a lot of importance. These SHPIs are several NGOs operating in all the states of North East and are key stakeholders in one of the streams of micro finance. It is worthwhile to mention that Department of Rural Development (under SGSY), Government of Assam is the largest promoter of SHG in the state of Assam.

To measure the perception of stakeholders about on whose perspective parameters to be considered for assessing Quality of SHG, sixty one quality assessment parameters are identified from the survey of literature and resultant perceived quality parameters are assessed. To prove the statistical hypothesis, we resorted to Nonparametric Test i.e. Kruskal Wallis Test on overall score to arrive at a conclusion. It is observed from the analysis on overall score that there exists enough evidence to conclude that there are differences among the opinion of the direct stakeholders of SHGs regarding the parameters to be considered while assessing the quality of SHGs. Moreover, cross tabulation analysis is conducted to analyse the perception of different stakeholders of SHGs (expressed in percentage) while determining the quality indicators of SHGs. It is observed that on thirty nine parameters, all the stakeholders of SHGs i.e. promoters or donors or financial institutions or group itself has perceived high level of desire to assess the quality of SHGs while on four parameters they have low level of desire to assess the quality of SHGs at their own perspective.

\section{Generalisation of Research Findings}

In traditional quantitative social research the problem of generalisation is discussed under the concept of external validity (of experimental studies) wherein would the same result be found under a different set of circumstances are analysed [ 63 ]. Again, in quantitative research, generalisability is considered a major criterion for evaluating the quality of a study $[64,65]$. A familiar criticism of qualitative methodology questions the value of its dependence on small samples which is believed to render it incapable of generalising conclusions $[66,67,68$, 69]. Further, Radhakrishna \& Doamekpor, 2008[70] in their article "Strategies for Generalising Findings in Survey Research' argued that random sample which somewhat limits the external validity of the study because of non response of respondents. Indeed, generalisation represents an active process of reflection [71]. Firestone, 1993[72] developed a typology depicting three models of generalisability that provides a useful framework for considering generalisations in quantitative and qualitative studies viz. Statistical generalisation, analytic generalisation and case-to-case translation (transferability). The present study featured statistical generalization, since it is based on random sampling which give every member of the population an equal chance to be included in the study with a determinable probability of selection [73]. The present study is considered to be have general acceptability as a whole to the present socio-economic set up of the study area since the sample was selected randomly from the population and there was a low proportion of refusals and dropouts i.e. below 30\% [74]. Further, the present study also satisfy the third model of generalisability i.e. case-tocase translation or reader generalisability [ 75 ] or transferability [76], since similar finding are also observed by other researchers in different contexts (external validity/ proximal similarity). Some of the findings of the present study about group's members and financial institutions strong perception towards some specific quality assessment parameters are also supported by some earlier research findings. The present study virtually supports the earlier study of Das, 2012a[77] while studying the quality issues and perceptions of SHG member's in the context of Barak Valley of Assam observed that (a) 'Financial management' is the most critical factor where respondents are supporting highly followed by 'Plans \& Vision', (b) 'Organisational capacity' and 'Saving \& credit' are among the some other parameters which are perceived at higher level, (c) 'Empowerment and Influence' \& 'Awareness and attitudes' undertaken by group/members are perceived as less supportive parameters in measuring quality of SHGs. Kavitha, Jiji, \& Rajkamal, 2011[78] observed members' perception of effectiveness of group functioning mainly on in terms of the quality of official procedures comprising of discipline, accountability, transparency and equity. These elements are also strongly perceived in this present study. Similarly, the finding of the present study about group member's strong desire to assess quality of SHG on the elements of empowerment and awareness of members is also revealed in the study of Meena \& Singh, 2012[79]. Dhar et al., 2008[80] while studying SBLP in India and consequent bankers perceptions on this regard observed that the main problem were timely communication with these bodies, lack of understanding of banking operations by the members, faulty identification of beneficiaries etc. which are also perceived by the financial institutions in the present study. Thus, the present finding is of profound 
implications since attitudes \& perceptions guide behaviour toward valued goals and away from aversive events [81]. In fact, the present study is totally a new dimension of SHGs quality assessment (though is it extension of earlier works of Sa-Dhan, 2003 on some unresolved issues ) hence justification regarding generalisation of present finding needs further research and future investigation in the same subject area and in the same construct. Moreover, the lack of analytic generalisation of the present study may be considered as one of the limitation of the study.

\section{References}

[1] Gladis Mary John (2008), "Women Empowerment through Self Help Groups", Southern Economist, March 1, pp. 23454.

[2] Minimol, M. C. and Makesh, K. G. (2012), "Empowering rural women in Kerala: A study on the role of Self Help Groups", International Journal of Sociology and Anthropology, November, 4(9), pp. 270-80. [Online]. Available: http://www.academicjournals.org/IJSA; DOI: 10.5897/IJSA12.003 [Accessed February 4, 2013].

[3] Sajeev, B. U. \& Thangavel, K. (2011), "Assessment of Financial Status of SHG Members: A Clustering Approach”, International Journal of Computer Applications, October, 32(2), pp. 7-15.

[4] State of the Sector Report (2006), "Microfinance in India: State of the Sector Report 2006". [Online]. Available: http://www.microfinanceindia.org/download.../state_of_the sector_06.pdf. [Accessed March 1, 2010].

[5] Economic Survey (2012), "Government of Assam, 2011-12", [Online].

Available: http://ecostatassam.nic.in/ads_economic\%20survey.pdf. [Accessed March 1, 2013].

[6] NRLM Report (2009), "India's National Rural Livelihoods Mission an Overview". [Online]. Available: http://siteresources.worldbank.org/INDIAEXTN/Resources/ india-NRLM-overview.pdf. [Accessed March 1, 2010].

[7] Fernandez, Aloysius P. (2006), "History and spread of the self-help affinity group movement in India: The role played by IFAD”, Occasional Papers- Knowledge for development effectiveness, July. [Online]. Available: http://myrada.org/myrada/docs/history3 sag_ifad.pdf.

[8] BASICS (2007), "A Study on SHG-Bank Linkage and Status of MFI in Bihar", Bihar Rural Livelihoods Promotion Society, Bihar, Bhartiya Samruddhi Investments and Consulting Services Ltd. [Online]. Available: http://www.basixindia.com. [Accessed February 23, 2013].

[9] Reddy, C. S. \& Prakash, L. B. (2003), "Status of SHG Federations in Andhra Pradesh: APMAS Assessment Findings" paper presented at SHG Federation Workshop Organised by NIPCCD and Sa-Dhan, March, pp. 24-25.

[10] Devaprakash, R. (2005), "Balancing Quality and Quantity in SHGs in India", IBA Bulletin, August, pp. 25-35. [Online]. Available:

http://www.microfinancegateway.org/.../27852_file_IBA_A ug_issue_1DE. [Accessed February 15, 2010].
[11] Kumar, Sunil (2010), "Study on SHG Federations: Challenges and Opportunities", Centre for Microfinance Research, Bankers Institute of Rural Development, Lucknow. [Online]. Available: http://www.birdlucknow.in/doc/REPORT\%20ON\%20SHG \%20FEDERATIONS.pdf. [Accessed February 15, 2012].

[12] Sinha, Anand (2012), "Strengthening governance in Microfinance Institutions (MFIs): some random thoughts", Keynote address at Federation of Indian Chambers of Commerce and Industry's (FICCI) workshop on Strengthening Microfinance Institutions (MFIs) - good governance and strategic people practices at Mumbai. 23 April 2012. [Online]. Available: http://www.bis.org/review/r120430e.pdf. [Accessed October $15,2013]$.

[13] Reddy, C. S. (2005), "SHGs: A Keystone of Micro Finance in India: Women empowerment \& Social Security". [Online]. Available: http:/ www.self-help-approach.com. [Accessed February 15, 2010].

[14] Sen, Manab \& Sircar, Ashok (2006), "Study of SHG \& MF sector in West Bengal with special reference to CASHE", Action research project to Loka Kalyan Parishad, August. [Online]. Available: http://www.lkp.org.in/pub/Study_Rpt/Study_SHG_MF.pdf. [Accessed February 15, 2010].

[15] APMAS Assessment Findings (2006), "Status of SHG Federations in Andhra Pradesh". [Online]. Available: http://www.microfinancegateway.org. [Accessed June 15, 2010].

[16] Singh, Jai Pal (2006), "PEDO's SHG Programme Impact Assessment, A Draft Report", Centre for Microfinance, Jaipur. [Online]. Available: http://www.solutionexchangeun.net.in/mf. [Accessed June 15, 2010].

[17] Sharma, A. (2007), "Expanding outreach to underserved regions: Kick-starting microfinance in North-Eastern Region”, Indian Institute of Bank Management, Guwahati.

[18] Government of Haryana (2007), "Self-Help Group Capability Assessment", Haryana Community Forestry Project- Forest Department, Govt. of Haryana. [Online]. Available: http://www.hcfp.gov.in/downloads/studies/SHG Capability Assessment_Study.pdf. [Accessed February 15, 2010].

[19] Roy, Durgadas (2007), "Mid-term Evaluation of the composition and working of Swarnajayanti Gram Swarozgar Yojana in 24 Parganas South District, West Bengal". [Online]. Available: http://www. planningcommission.nic.in. [Accessed February 15, 2010].

[20] Sahu, Gagan Bihari (2010), "SHG Bank Linkages in North West India", Center for Microfinance Research, BIRD, Lucknow.

[21] Josily, Samuel (2006), "Women Empowerment through Microfinance in Dindigul District of Tamil Nadu: An Economic Analysis, M.Sc. (Agri.) Thesis. Department of Agricultural Economics. University of Agricultural Sciences, Dharwad, India. [Online]. Available: http://etd.uasd.edu. . [Accessed February 15, 2012].

[22] ASEED (2007), "Comparative study of SGSY and NABARD supported SHGs initiatives in Northern India”, Asian Society for Entrepreneurship Education and 
Development, ASEED, New Delhi, pp. 143.

[23] Feroz, S. M. \& Chauhan, et al. (2009), "Determinants of Repayment Performance of Self Help Groups: Empirical Evidence from India”, in Lazar, D and Malabika Deo (Ed.), Micro Finance - Performance Evaluation and Enterprise Development (pp. 199-206), Allied Publishers, Chennai.

[24] Srinivasan, N. (2009), Micro finance India- State of the Sector Report 2009, ACCESS, New Delhi. [Online]. Available: http://www.microfinancegateway.org. [Accessed February 15, 2010].

[25] Henriques, Elizabeth Joey \& Gaonkar, Rekha Ramesh (2011), "Micro-Credit: A study of Micro- credit Usage by SHG Members in Goa", International Journal of Research in Commerce, Economics \& Management, 1(3), pp. 56-60.

[26] Das, Sanjay Kanti (2012), "Ground Realities of Self Help Group-Bank Linkage Programme: An empirical analysis", International Journal of Research in Social Sciences, 2 (2), pp. 464-79.

[27] Das, Sanjay Kanti (2012), "Best Practices of Self Help Groups and Women Empowerment: A Case of Barak Valley of Assam", Far East Journal of Psychology and Business, Far East Research Centre, 7(2), pp. 29-51.

[28] Das, Sanjay Kanti (2012), "Quality and Performance of Some Selected Self Help Groups in Assam", Asian Journal of Research in Business Economics and Management, II (IV), pp. 21-27.

[29] Sa-Dhan (2005), "SHG Performance Measurement Tool", Technical Tool Series 2. [Online]. Available: http://www.sadhan.net/Adls/Microfinance/Article. [Accessed February 15, 2009].

[30] Sa-Dhan (2003), "Quality Parameters of SHGs- A discussion paper", [Online]. Available: http://www.sadhan.net. [Accessed February 15, 2013].

[31] Reddy, C. S. (2005), "SHGs- A Keystone of Micro Finance in India: Women empowerment \& Social Security". [Online]. Available: http:/ www.self-help-approach.com. [Accessed February 15, 2010].

[32] Sen, Manab \& Sircar, Ashok (2006), "Study of SHG \& MF sector in West Bengal with special reference to CASHE", Action research project to Loka Kalyan Parishad, August. [Online]. Available: http://www.lkp.org.in/pub/Study_Rpt/Study_SHG_MF.pdf. [Accessed February 15, 2009].

[33] APMAS Assessment Findings (2006), "Status of SHG Federations in Andhra Pradesh". [Online]. Available http://www.microfinancegateway.org. [Accessed February $15,2010]$.

[34] Centre of Micro Finance Research (2007), "Feasibility Study of a Special Purpose Vehicle (SPV) for SHG financing through SHG Institutions", Centre of Micro Finance Research, Jaipur. [Online]. Available: http://www.cmfraj.org/Feasibility\%20study\%20on\%20Speci al\%20Purpose\%20Vehicle.pdf. [Accessed June 15, 2010].

[35] Government of Haryana (2007), "Self Help Group Capability Assessment", Haryana Community Forestry Project- Forest Department, Govt. of Haryana. [Online]. Available:
http:/hcfp.gov.in/downloads/studies/SHG_Capability_Asses sment_Study.pdf. [Accessed February 15, 2010].

[36] Roy, Durgadas (2007), "Mid-term Evaluation of the composition and working of Swarnajayanti Gram Swarozgar Yojana in 24 Parganas South District, West Bengal". [Online]. Available: http://wwww. planningcommission.nic.in. [Accessed February 15, 2010].

[37] Sharma, Jaya (2008), "Empowerment, Poverty Alleviation \& Education within SHGs", paper presented in a Round Table on A Vision for SHGs in Rajasthan: From Social Mobilization to Social Capital, at Gold Palace \& Resorts, Kukas, Amer. 30-31 July 2008. [Online]. Available: http://www.aravali.org.in/VisionSHG.pdf. [Accessed February 15, 2010].

[38] [38] Parashar, D. N. (2008), "SHG Strengthening", paper presented in Round Table on A Vision for SHGs in Rajasthan- From Social Mobilization to Social Capital, at Gold Palace \& Resorts, Kukas, Amer. 30-31 July 2008. [Online]. http://www aravali.org in/VisionSHG pdf. February 15, 2010].

[39] Bhanawat, Rajendra (2008), "Financing SHG, Strengthening and Promotion", paper presented in a Round Table on A Vision for SHGs in Rajasthan: From Social Mobilization to Social Capital at Gold Palace \& Resorts, Kukas, Amer. 3031 July 2008. [Online]. Available: http://www.aravali.org.in/VisionSHG.pdf. [Accessed February 15, 2010].

[40] Shetty, Naveen K. (2009), "Index of Microfinance Group Sustainabilit: Concepts, Issues and Empirical Evidence from Rural India", The microFINANCE REVIEW, Journal of the Centre for Microfinance Research, 1(1), pp. 131-52.

[41] Sahu, Gagan Bihari (2010), "SHG Bank Linkages in North West India", Center for Microfinance Research, BIRD, Lucknow.

[42] Vipinkumar, V. P., Sahoo, Prabhati Kumari, Krishna Srinath, T. V. Ambrose, Shakya Sahay Jiban Das (2013), "Gender perspectives and dynamics of bivalve farming Self Help Groups", Indian Journal of Fisheries., 60(3), pp. 59-66.

[43] Vipinkumar, V. P. and Singh Baldeo (1998), "Dimensions of Self Help Group dynamics of horticulture farmers", Journal of Extension Education, 3 (1\&2), pp. 1- 9.

[44] APMAS (2007), "SHG-Bank Linkage Programme: A Recurrent Study in Andhra Pradesh", Communication Division of APMAS. [Online]. Available: http://www.apmas.org/pdf/SHG-\%20Bank\%20 Linkage\%20. [Accessed February 15, 2010].

[45] Roy, Arup (2011), "Quality of Services of the MFIs of Assam", North East Economic Review, 1(1), pp. 36-50.

[46] Sa-dhan (2003), "Quality Parameters of SHGs: A Discussion Paper, Discussion Series 2, August. [Online]. Available: http://www.sa-dhan.org. [Accessed February 15, 2009].

[47] Comrey, A, L. (1973), A first course in factor analysis, New York: Academic Press.

[48] Nunnally, J. C. (1978), Psychometric Theory (2nd ed.), New York: McGraw-Hill. 
[49] Gorsuch, R. L. (1983), Factor analysis (2nd ed.), Hillsdale, NJ: Lawrence Erlbaum.

[50] Oppenheim, A. N. (1992), Questionnaire Design, Interviewing and Attitude Measurement, London- Pinter Publishers.

[51] Coakes, S. J. and Steed, L. G. (1997), SPSS Analysis without Anguish, Brisbane: John Wiley \& Sons.

[52] Cronbach, L. J. (1951), "Coefficient alpha and the internal structure of tests", Psychometrika, 16(3), pp. 297-334.

[53] Nunnally, J. C. and Bernstein, I. H. (1994), Psychometric Theory (3rd ed.), McGraw-Hill- New York.

[54] George, D. \& Mallery, P. (2003), SPSS for Windows step by step- A simple guide and reference, 11.0 update (4th ed.), Boston, Allyn \& Bacon, pp. 231.

[55] Alreck, P. L. \& Settle, R. B. (1995), The survey research handbook (2nd Ed.), Boston, MA- Irwin McGraw-Hill.

[56] Gaddis, S. E. (1998), "How to design online surveys?" Training and Development Journal, 52(6), pp. 67-71.

[57] Leedy, P. D. \& Armrod, J. E. (2001), Practical research (7th ed.), Upper Saddle River, N J- Prentice-Hall.

[58] Long L. (1998), Surveys from start to finish. Alexandria, VA- American Society for Training and Development.

[59] Singh, Ranjit \& Bhowal, Amalesh (2010). "Marketing Dimension of Equity related Risk Perception of Employees: Own Company's Shares vs. Other Company's Shares", Management Insight, Dec., VI (2), pp. 22-36. [Online]. Available:

http://inflibnet.ac.in/ojs/index.php/MI/article/view/897. [Accessed November, 3, 2013].

[60] Singh, Ranjit \& Bhowal, Amalesh (2011), "Development of marketing-driven measure of risk perception", Journal of Risk Finance, 12(2), pp. 140-52.

[61] Kristin Rasmussen (2007), "Interval Level of Measurement", In Neil J. Salkind \& Kristin Rasmussen (ed.), Encyclopedia of Measurement and Statistics, SAGE Research Methods. DOI: http://dx.doi.org/10.4135/9781412952644 . [Online]. Available: http://srmo.sagepub.com/view/encyclopedia-ofmeasurement-and-statistics/n225.xml. [Accessed November, 3, 2013].

[62] Green, S. B., \& Salkind, N. J. (2008), Using SPSS for Window and Macintosh: Analyzing andunderstanding data (5th ed.), Pearson Prentice Hall, Upper Saddle River, NJ.

[63] Sarafino, Edward P. (2005), Research methods. Using processes and procedures of science to understand behaviour, Pearson/Prentice Hall, Upper Saddle River.

[64] Kerlinger, F. N. \& Lee, H. B. (2000), Foundations of Behavioral Research, (4th ed.), Harcourt College Publishers, Fort Worth, TX.

[65] Polit, D. F. \& Beck, C. T. (2008), Nursing Research: Generating and Assessing Evidence for Nursing Practice, (8th ed.), Lippincott Williams \& Wilkins, Philadelphia, PA.

[66] Hamel, J., Dufour, S., \& Fortin, D. (1993), Case study methods, Sage Publications, Newbury Park, CA.
[67] Yin, R. (1984), Case study research: Design and method, Sage Publications, Beverly Hills, CA.

[68] Yin, R. (1993), Applications of case study research, Sage Publications, Beverly Hills, CA.

[69] Yin, R. (1994), Case study research: Design and method (2nd ed.), Sage Publications, Beverly Hills, CA.

[70] Radhakrishna, Rama \& Doamekpor, Prosper (2008), "Strategies for Generalizing Findings in Survey Research", Journal of Extension, 46 (2). [Online]. Available: http://www.joe.org/joe/2008april/ttlp.shtml. [Accessed Oct, $30,2013]$

[71] Greenwood, D. J., \& Levin, M. (2000), "Reconstructing the relationships between universities and society through action research", in N. K. Denzin \& Y. S. Lincoln (Eds.), Handbook of qualitative research (2nd ed., pp. 85-106), Sage Publications, Thousand Oaks, CA.

[72] Firestone, W.A. (1993), "Alternative arguments for generalizing from data as applied to qualitative research", Educational Researcher, 22, pp. 16-23.

[73] Polit, D. F. (2010), Statistics and Data Analysis for Nursing Research, (2nd ed.), Pearson Education, Upper Saddle River, NJ.

[74] Will G Hopkins (1999), "How to write a literature review", Sportscience, 3(1). [Online]. Available: http://sportsci.org/jour/9901/wghreview.html. [Accessed Oct $30,2013]$.

[75] Misco, T. (2007), "The frustrations of reader generalisability and grounded theory: alternative considerations for transferability", Journal of Research Practice, 3, pp. 1-11.

[76] Lincoln, Y., Guba, E. (1985), Naturalistic Inquiry, Sage Publications, Beverly Hills, CA.

[77] Das, Sanjay Kanti (2012a), "Quality Issues and Perceptions of Self Help Group Member's about Quality Assessment: A case study of Barak Valley of Assam", Asian Journal of Management, 3(2), pp. 99-108.

[78] Kavitha, V., Jiji, R. S. \& Rajkamal, P. J. (2011), "Perception of effectiveness of group functioning by the members of women self-help groups in goat farming", Veterinary World, 4(11), pp. 507-10. [Online]. Available: doi: 10.5455/vetworld.2011.507-510[Accessed Oct, 30, 2013].

[79] Meena, M. S. \& Singh, K. M. (2012), "Measurement of Attitude and Behavior of Self-help Group Members: Evaluative Study of Eastern India”, MPRA Paper No. 46902 [Online]. Available: http://mpra.ub.unimuenchen.de/46902/1/MPRA_paper_46902.pdf. [Accessed Oct, 30, 2013].

[80] Dhar, Samirendra Nath, Kiranjit Sett, \& Sarkar, Soumitra (2008), "SHG-Banknig in India-Empirical Evidences of Banker's Perception \& Problems", Vidyasagar University Journal of Commerce, March, 13,pp. 54-65.

[81] Baron, R.A. and Byrne, D. (1993). Social PsychologyUnderstanding human interaction, 16nth edition, Prentice Hall of India Pvt. Ltd., New Delhi.p.142. 